\title{
MALE RAPE AND SEXUAL CRIMES IN INTERNATIONAL CRIMINAL LAW JURISPRUDENCE: A CRITICAL APPRAISAL
}

\author{
VIOLACIÓN MASCULINA Y CRÍMENES SEXUALES EN LA \\ JURISPRUDENCIA DEL DERECHO PENAL INTERNACIONAL: \\ UNA APRECIACIÓN CRÍTICA
}

\author{
DIMITRIS LIAKOPOULOS*
}

Recibido: 22/06/2018

Aceptado: 16/07/2018

SUMARIO: 1. INTRODUCCIÓN; -2. LA DEFINICIÓN DE VIOLACIÓN POR PARTE DE LA CORTE PENAL INTERNACIONAL; -3. SUPERAR EL TABÚ DE LOS HOMBRES VÍCTIMAS DE VIOLENCIA SEXUAL; -4. VACÍO LEGAL Y JUDICIAL EN LA VIOLENCIA CONTRA LOS HOMBRES; -5. EL NUEVO DOCUMENTO DE POLÍTICA DE LA FISCALÍA DE LA CPI: ABORDAR LAS LAGUNAS EN LA JUSTICIA PENAL INTERNACIONAL; -6. PERSPECTIVAS Y SUGERENCIAS; -7. CONCLUSIONES.

SUMMARY: 1.INTRODUCTION; -2. THE DEFINITION OF RAPE BY THE INTERNATIONAL CRIMINAL COURT; -3. OVERCOMING THE TABOO OF MALE VICTIMS OF SEXUAL VIOLENCE; -4. LEGAL AND JUDICIAL VACUUM IN VIOLENCE AGAINST MEN; -5. THE NEW POLICY DOCUMENT OF THE ICC PROSECUTOR'S OfFICE: ADDRESSING THE GAPS IN INTERNATIONAL CRIMINAL JUSTICE; -6. PROSPECTS AND SUGGESTIONS; -7. CONCLUSIONS.

Resumen: El presente trabajo ha intentado analizar crímenes sexuales y especialmente el crimen de violación masculina. La jurisprudencia internacional de los Tribunales penales internacionales y la Corte Penal Internacional ha tratado de calificar la violación como un crimen de genocidio en forma de graves lesiones físicas y corporales, aunque no necesariamente permanente (letra. B) art. 6 del Estatuto de Roma; o como un crimen contra la humanidad cuando existen elementos de contexto y, sobre todo, elementos materiales que surgen de las definiciones dadas por los Tribunales especiales y los elementos de los crímenes; o incluso como un crimen de guerra en caso de que se implemente como parte de un plan o diseño político, o como parte de una serie de crímenes similares cometidos a gran escala. Debido a la falta de tratamiento de un delito "particular" y difícil de probar o testificar ante un tribunal internacional. La indicación del nivel de gravedad del delito es necesaria para la relevancia de la violencia sexual y la violación como crímenes de lesa humanidad que veremos en los próximos años desde el panorama del derecho penal.

\footnotetext{
* Full professor in Fletcher School-Tufts University (MA in law in international law and MA of Arts in law and diplomacy). Chair of European Union Law. Full professor in international criminal law and criminal procedural law in De Haagse Hogenschool-Aja. Attorney at Law a New York and Bruxelles. ORCID number: 0000-0002-1048-6468. The present work is updated until July 2018.
}

https://dx.doi.org/10.17561/rej.n10.a4

Revista de Estudios Jurídicos nº 18/2018 (Segunda Época)

ISSN-e 2340-5066. Universidad de Jaén (España)

Versión electrónica: rej.ujaen.es 
Palabras clave: Derecho penal internacional, Corte criminal internacional, crimen de violación, crímenes sexuales, genocidio

Abstract: The present work has attempted to analyze sexual crimes and especially the crime of male rape. The international jurisprudence of international criminal Tribunals and the International Criminal Court has tried to qualify rape either as a crime of genocide in the form of serious bodily and physical injuries, even if not necessarily permanent (lett. b) art. 6 of the Rome Statute; or as a crime against humanity where there are elements of context and above all material elements that emerge from the definitions given by the ad hoc Tribunals and the elements of crimes; or even as a war crime in case it is implemented as a part of a political plan or design, or as part of series of similar crimes committed on a large scale. Due to the lack of dealing with a "particular" crime and difficult to prove it or testify before an international Court. The indication of the level of gravity of the crime is necessary for the relevance of sexual violence and rape as crimes against humanity that we will see in the next years from the panorama of international criminal law.

Keywords: international criminal law, International Criminal Court, crime of rape, sexual crimes, genocide

\section{INTRODUCTION}

The latest military developments/actions in Syria (April 2018) remind us once again the "huge volume of overwhelming testimonies", pictures and videos that document the so-called report: "Implementation of the Resolution establishing the international, impartial and independent mechanism to assist in the investigation and prosecution of person responsible for the most serious crimes under international law committed in the Syrain Arab Republic since March 2011"1, led by the French judge K. Marchi-Uhel, who has conducted preliminary investigations into a number of cases and cooperates with judges that investigate war crimes in different countries ${ }^{2}$. This investigation has stated that: "evidence of sexual crimes is overwhelming, but the cases are so many that no prosecution can be brought for all" 3 . Despite this finding of "impunity" by international criminal law ${ }^{4}$ for serious sexual crimes ${ }^{5}$ jurisprudence still know proved that: International criminal law has been vital in fostering the understanding of sexual violence against male in armed conflict as a weapon of war that targets not only a woman but a male role in international society ${ }^{6}$.

\footnotetext{
${ }^{1} \mathrm{GA}, 71^{\text {th }}$ of 16 August 2017, A/71/755/Add.1.

${ }^{2}$ ACQUAVIVA G., War crimes at the ICTY: Jurisdictional and substantive issues, in BELLELLI R. (a cura di), International criminal justice. Law and practice from the Rome Statute to its review, Ashgate publishing, 2010, pp. 299ss. WATERLOW J., SCHUHMACHER J., War crimes trials and investigations. A multidisciplinary introdcution, Oxford University Press, 2018.

${ }^{3}$ AMBOS K., Internationales Strafrecht, C.H. Beck, 2018.

${ }^{4}$ MELLOH F., Einheitliche Strafzumessung in den Rechtsquellen des ICC-Statuts, Dunker\&Humblot, 2010. ${ }^{5}$ ABTAHI H., KOH S.A., "The emerging enforcement practice of the International Criminal Court", in Cornell International Law Journal, 2012, pp. 1ss. MOUTHAAN S., "Sexual violence against men and international law criminalising the unmentionable", in International Criminal Law Review, 2013, pp. 667ss. ${ }^{6}$ EBOE-OSUJI C., International law and sexual violence in armed conflicts, ed. Brill, 2012, pp. 146ss. AMBOS K., Treatise on unternational criminal law: vol. 2: The crimes and sentencing, Oxford University Press, 2014. MIBENGE C.S., Sex and international Tribunals: The erasure of gender from the war
} 
The developments in international criminal case law, in respect of the recognition that sexual crimes fall within the scope of war crimes ${ }^{7}$ and crime against humanity and genocide crime ${ }^{8}$, have been overshadowed by the often frivolous treatment of these crimes by the international criminal justice ${ }^{9}$.

The remnants that have prevailed over these centuries for these crimes, that they were a by-product of the war ${ }^{10}$, or that in any case they are incidental and secondary to the main crimes, did not allow the provisions of the Statutes to be applied to a sufficient level ${ }^{11}$. The lack of previous international jurisprudence has found the international criminal Courts in a position to be forced to make unstable interpretations or even to develop an important case-law which has often been questioned by the Courts themselves ${ }^{12}$. The interpretations, of course, have often led to the departure from the mechanistic perception of justice and the adoption of the aim towards full recognition of the victims' human rights ${ }^{13}$. Other times, the principle of feasibility in the prosecution has prevailed, to such an extent that it has led to several cases of impunity for perpetrators of crimes of sexual violence ${ }^{14}$. These failures were complemented by the inherent difficulty of dealing with these crimes as a result of the psycho social impact of sexual violence on victims ${ }^{15}$. These difficulties are often insurmountable even at the level of domestic criminal systems, where correlations become even more complicated and inaccessible to resolving them. Even in the most recent criminal Courts judiciary officers were not prepared to deal with the broadness and specificity of sexual offenses. The lack of proper staff, the lack of understanding of the law, and the general politicization of many affairs, have led to results that are highly controversial and criticized ${ }^{16}$.

narrative, University of Pennsylvania Press, 2013.

${ }^{7}$ HELLER K.J., SIMPSO G. (eds), The hidden histories of war crimes trials, Oxford University Press, 2013. ${ }^{8} \mathrm{~A} / \mathrm{HRC} / 37 / 65$ of $1^{\text {st }}$ March 2018: Human Rights Council: Joint study of the Special Rapporteur on the promotion of truth, justice, reparation and guarantees of non-recurrence and the Special Adviser to the Secretary-General on the Prevention of Genocide. See in argument also: MARCZAK N., SHIELDS K., Genocide perspective V: A global crime, UTS ePress, 2017. SÁNCHEZ REVERTE A., "Referencia al crimen de genocidio aproximation genocide crime", in Revista de Estudios Juridicos (segunda època), 2016. ${ }^{9}$ BABINGTON-ASHAYE A., COMRIE A., ADENIRAN A., International criminal investigations: Law and practice, Eleven International Publishing, 2018. LIAKOPOULOS D., Parità di armi nella giustizia penale internazionale, vol. 1, ed. Libellula University Press, 2018.

${ }^{10}$ PARASHAR S., "What wars and "war bodies" know about international relations", in Cambridge Review of International Affairs, 2013, pp. 621ss.

${ }^{11}$ AMBOS K., Sexual offences in international criminal law, with a special focus on the Rome Statute of the International Criminal Court (July 3, 2012), in BERGSMO M., BUTENSCHØN A., SKRE WOOD E.J. (eds.), Understanding and proving international sex crimes, Torkel Opsahl Academic Epublisher, Beijing, 2012, pp. 144ss.

${ }^{12}$ RAMJI-NOGALES J., "Questioning hierarchies of harm: Women, forced migration and international criminal law”, in International Criminal Law Review, 2011. HALLEY J., "Rape in Berlin: Reconsidering the criminalisation of rape in the international law of armed conflict", in Melbourne Journal of International Law, 2008, pp. 80ss.

${ }^{13}$ PILLAY N., "Sexual violence: Standing by the victim”, in Case Western Reserve Journal of International Law, 2009, pp. 462ss.

${ }^{14}$ BROWN B.S., Research handbook on international criminal law, Edward Elgar Publishing, 2011, pp. 86ss. COLE A., International criminal law and sexual violence, in MCGLYNN C., MUNRO V.E., Rethinking rape law. International and comparative perspectives, ed. Routledge, 2010, pp. 49ss.

${ }^{15}$ BACHAROVA T., The standing of victims in the procedural design of the ICC, ed. Brill, 2017.

${ }^{16}$ ACEVEDO P.L., "The legitimacy of international criminal Tribunals", in Nordic Journal of Human Rights, 2017, pp. 164ss. 


\section{THE DEFINITION OF RAPE BY THE INTERNATIONAL CRIMINAL COURT}

The Preparatory Committee on the International Criminal Court was mainly influenced by the ICT for the Former Yugoslavia and the ICT of Rwanda case-law and the elements of crimes, a text intended to assist the Court in the interpretation and application of Articles 6 (genocide), 7 (crimes against humanity) and 8 (war crimes). Of course, in the International Criminal Court, the elements of rape are the same, regardless of whether rape is prosecuted as a war crime ${ }^{17}$ or a crime against humanity ${ }^{18}$. Thus, rape is defined as follows: 1. The offender violated a person's body by actions that resulted in the penetration, regardless of gravity, of any part of the body of the victim or the accused with a sexual organ, or of the oral or rectal cavity victim with any object or part of the body $^{19} .2$. The violation was committed with violence or threat of violence or coercion such as that caused by fear of violence, coercion, detention, psychological oppression or abuse against such person or other person or through exploitation of the enforced environment ${ }^{20}$, or the violation was brought against of a person unable to give genuine consent. This definition of the International Criminal Tribunal (ICT) is a mixture of definitions given by the ICT for the Former Yugoslavia, of Rwanda and Rule $96^{21}$ of the

\footnotetext{
${ }^{17}$ SVÁČEK O., "Brothers and sisters in arms as victims of war crimes. Ntagada case before the ICC", in Czech Yearbook of Public \& Private International Law, 2018.

${ }^{18}$ See from the ICTR the next cases: Prosecutor v. Bagosora, Kabiligi, Ntabakuze, Nsengiyumva, ICTR-9841-T, judgment and Sentence, 18 Dec 2008; Prosecutor v. Bikindi, ICTR-01-72-T, judgment, 2 Dec 2008; Prosecutor v. Bisengimana, ICTR-00-60-T, judgment and Sentence, 13 Apr 2006; Prosecutor v. Bizimungu (Casimir), Mugenzi, Bicamumpaka and Mugiraneza, ICTR-99-50-T, Decision on Defence Motions Pursuant to Rule 98 Bis, 31 Oct 2005; Prosecutor v. Nizeyimana and Hategekimana, ICTR-00-55-I, Decision on the Prosecutor's Application for Severance and Leave to Amend the Indictment against Idelphonse Hategekimana, 25 Sept 2007; Prosecutor v. Elizaphan and Gerard Ntakirutimana, ICTR-96-10 and ICTR-96-17-T, judgment and Sentence, 21 Feb 2003; Prosecutor v. Nyiramasuhuko, Kanyabashi, Ndayambaje, Nsabimana, Ntahobali, Nteziryayo, ICTR-98-42-T, Decision on Defence Motions for Acquittal under Rule 98bis, 16 Dec 2004; Prosecutor v. Rugambarara, ICTR-00-59-T, Sentencing judgment, 16 Nov 2007; Prosecutor v. Rutaganira, ICTR-95-1C-T, judgment and Sentence, 14 Mar 2005; Prosecutor v. Seromba, ICTR-2001-66-A, judgment, 12 Mar 2008. AGNEW A., “Acquittals in Mugenzi \& Mugiraneza v. Prosecutor contribute to the weak legacy of the International Criminal Tribunal for Rwanda", in Boston College International \& Comparative Law Review, 2015, pp. 8ss.

${ }^{19}$ AHMAD H., "Context at the International Criminal Court", in Pace International Law Review, 2017, pp. 132ss.

${ }^{20}$ ALEXANDER JF., "The International Criminal Court and the prevention of atrocities: Predicting the Court's impact", in Villanova Law Review, 2009, pp. 27ss.

${ }^{21}$ The Rule 96 defines: In cases of sexual assault: (i) Notwithstanding Rule 90 (C), no corroboration of the victim's testimony shall be required; (ii)Consent shall not be allowed as a defense if the victim: (a) Has been subjected to or threatened with or has had reason to fear violence, duress, detention or psychological oppression; or (b) Reasonably believed that if the victim did not submit, another might be so subjected, threatened or put in fear; (iii) Before evidence of the victim's consent is admitted, the accused shall satisfy the Trial Chamber in camera that the evidence is relevant and credible; (iv) Prior sexual conduct of the victim shall not be admitted in evidence or as defense. See, Rule 96 of Evidence and Procedure (UN Doc. IT/32, 1 Feb. 1994). Position adopted in case: Prosecutor v. Tadić, the ICTY trial chamber explained: "(...) that the rule rejecting a corroboration requirement in sexual assault cases accords to the testimony of a victim of sexual assault the same presumption of reliability as the testimony of victims of other crimes, something long denied to victims of sexual assault by the common law (...)". See in argument: SATZGER
} 
ad hoc Tribunals that is part of the rules and the proof process ${ }^{22}$. However, the ICT for Rwanda definition avoids a clear choice between the elements of Akayesu and Furundžija, but rather seems to combine them ${ }^{23}$. But it provides a gender-neutral definition ${ }^{24}$, predicting the physical penetration of any part of the victim's body as well as violence or coercion $^{25}$. However, although any sexual penetration, according to the definition, may be rape, the sexual conduct of the perpetrator who does not consist penetration is not covered by the rape crime ${ }^{26}$.

The condition of coercion has been broadly defined by the ICT for Rwanda in the Bemba appeal case ${ }^{27}$, where the Tribunal ruled that: "with regard to the term "coercion" 28 , the Court notes that it does not only require physical violence ${ }^{29}$. On the contrary, threats, intimidation, displacement, and other forms of cruelty based on fear or despair may be coerced, while coercion may be inherent in specific circumstances, such as armed conflicts or situations of military presence" ${ }^{30}$.

It remains to be seen, however, how the ICT for Rwanda and the ICC will further specify in its case-law each of the elements of crime, which are to be clarified in accordance with international criminal law and which procedural rules will be applied to ensure that it will not be required to the lack of consensus of the victim. It should also be noted that this definition is quite convincing and has been copied in the laws created by the Courts of Cambodia (Extraordinary Chambers in the Courts of Cambodia-ECCC) ${ }^{31}$

H., SCHLUCKEBIER W., WIDMAIER G., Strafprozessordung (StPO), Carl Heymanns Verlag, 2017.

${ }^{22}$ SATZGER H., SCHLUCKEBIER W., WIDMAIER G., Strafprozessordung (StPO), op. cit.,

${ }^{23}$ VISEUR-SELLERS P.V., "Gender strategy is not a luxury for international Courts”, in American University Gender, Society Policy \& Law, 2009, pp. 302ss.

${ }^{24}$ See in particular the next doctrine work: HAGAY-FREY A., Sex and gender crimes in the new international law: Past, present, future, Martinus Nijhoff Publishers, 2011, pp. 80ss.

${ }^{25}$ CHAPPELL L., The politics of gender justice at the International Criminal Court, Oxford University Press, 2016, pp. 266ss

${ }^{26}$ MOUTHAAN S., "The prosecution of gender-based crimes at the ICC: Challenges and opportunities", in International Criminal Law Review, 2011, pp. 776ss.

${ }^{27}$ ICC-01/05-01/08 of 21 March 2016. O’REGAN F., "Prosecutor vs. Jean-Pierre Bemba Gombo: The cumulative charging principle, Gender-based violence, and expressivism", in Georgetown Journal of International Law, 2012, pp. 1344ss.

${ }^{28}$ AMBOS K., ACKERMAN B., Liber amicorum Mirjam Damaška. Beitäge zum Internationalen und Europäischen Strafrecht, Duncker \& Humblot, 2016.

${ }^{29}$ In argument see also: the United Kingdom launched an initiative on preventing sexual violence in conflict, aimed, inter alia, at strengthening international efforts and coordination, and supporting states in building their national capacity to prosecute acts of sexual violence committed during conflict. See the G8 Declaration on Preventing sexual violence in conflict, 11 April 2013. The African Solidarity Initiative, a programme launched by the African Union ("AU") in 2012 to mobilise support for post-conflict reconstruction, has also brought about consultations with the objective of formulating an AU-led strategic framework for the prevention of, and response to, sexual violence in Africa. See: The concept note on highlevel consultation on preventing and responding to sexual violence in conflict, post-conflict countries and beyond, 9-11 October 2013. EBOE-OSUJI C., "The ICC and the African Court and the estended notion of complementarity of international criminal jurisdictions", in Nigeria Yearbook of International Law, 2018.

${ }^{30}$ ICC, Prosecutor v. Jean-Pierre Bemba Gombo, Decision Pursuant to Article 61(7)(a) and (b) on the Charges against Jean Pierre Bemba Gombo, Case No. ICC-01/05-01/08, 15 June 2009 (Bemba Confirmation Decision), para. 162.

${ }^{31}$ SÁCOUTO S., "Victim participation at the international Criminal Court and the Extraordinary Chambers in the Courts of Cambodia: A feminist project”, in Michigan Journal of Gender \& Law, 2012, pp. 298ss. PALMER E., WILLIAMS S.,” A “shift in attitude”? Institutional change and sexual and gender-based 
and the special panels for serious crimes in East Timor ${ }^{32}$, which have already been issued a conviction for the rape crime in the Cardoso case ${ }^{33}$. I suggest that they are worth exploring, as they hold out the possibility of complementing the inevitably limited narratives which emerge through criminal proceedings and bringing us closer to making the more complex and subtle narratives of women's experiences "fully visible" 34 .

In the end, we can say that the extensive efforts of the judges in the Courts of Former Yugoslavia and Rwanda to identify and develop the definition of rape as an international crime $^{35}$ provides a classic illustration of the operation of the case-law interpretation ${ }^{36}$. Akayesu is the perfect archetype of jurisprudence ${ }^{37}$, while Furundžija and Kunarac propose a more cautious approach, quite detailed, based on the principle of specialty. At the same time, other decisions, such as Musema and Muhimana ${ }^{38}$, attempt to create a harmonious interpretation of existing case law. However, although these efforts have been a milestone in international criminal jurisprudence and contributed to the development of international criminal law, this issue continues to concern the Courts and academics. The contradictory versions at times raises a number of concerns in the context of human rights law, and in particular the impact that different and often conflicting definitions may have on the right to equal access to justice. As Patricia Viseur Sellers points out, different definitions of rape may result in a 16-year-old girl in the civil war in Sierra Leone ${ }^{39}$ being

crimes at the Extraordinary Chambers in the Courts of Cambodia”, in International Feminist Journal of Politics, 2017. MEISENBERG S., The extraordinary Chambers in the Courts in Cambodia. Assessing their contribution to international criminal law, ed. Springer, 2016. DEFALCO R.C., "Accounting for famine at the Extraordinary Chambers in the Courts of Cambodia. The crimes against humanity of extermination, inhumane acts and persecution”, in The International Journal of Transitional Justice, 2011.

${ }^{32}$ SCHEFFER D., The Extraordinary Chambers in the Courts of Cambodia, in BASSIOUNI M.C., International Criminal Law, ed. Brill, 2008, pag. 253: noting that: "(...) the ECCC (...) was never conceived of by those who negotiated its creation as an instrument of direct relief for victims, although the protection and use of victims as witnesses in the investigations and trials is addressed in detail (...) there is no express provision in the agreement, as adopted, entitling victims to participate (...)". See also Agreement Between the United Nations and the Royal Government of Cambodia Concerning the Prosecution Under Cambodian Law of Crimes Committed During the Period of Democratic Kampuchea, June 6, 2003, 2329 U.N.T.S 141273. The Cambodian law implementing the agreement and establishing the ECCC references a right of victims to appeal against decisions of the ECCC Trial Chamber, it does not otherwise expressly permit victims to participate in ECCC proceedings. Law on the Establishment of the Extraordinary Chambers in the Courts of Cambodia for the Prosecution of Crimes Committed During the Republic of Kampuchea, NS/RKM/1004/006 (Oct. 27, 004). See also: JAIN N., Going beyond prosecutorial discretion: Institutional factors influencing thematic prosecution, in BERGSMO M., Thematic prosecution of international sex crimes, Beijing, 2012, pp. 208ss.

${ }^{33}$ The Prosecutor v. Jose Cardoso Fereira, Case No 04/2001, 5 April 2003.

${ }^{34}$ AMBOS K., STEGMILLER L., "Prosecuting international crimes at the International Criminal Court: Is there a coherent and comprehensive prosecution strategy?", in Crime, Law and Social Change, 2013.

${ }^{35}$ HELLER K.J., "What is an international crime?", in Harvard International Law Journal, 2018.

${ }^{36}$ DE GUZMAN M.M., "How serious are international crimes? The gravity problem in international criminal law", in Columbia Journal of Transnational law, 2012, pp. 20ss.

${ }^{37}$ CHIEDU MOGHALU K.C., "International humanitarian law from Nuremberg to Rome: The weighty precedents of the international criminal Tribunal for Rwanda”, in Pace International Law Review, 2002, pp. 285ss.

${ }^{38}$ NOVAK A., The International Criminal Court: An Introduction, ed. Springer, 2015.

${ }^{39}$ See from the Special Tribunal for Sierra Leone the next cases: Prosecutor v. Fofana and Kondewa, SCSL04-14-T, Judgment, 2 Aug 2007; Prosecutor v. Sesay and 2 others, SCSL-04-15-T, judgment, TC, 2 Mar 2009; Prosecutor v. Fofana and Kondewa, SCSL-04-14-A, Judgment, 28 May 2008; Prosecutor v. Sesay and 2 others, SCSL-04-15-T, judgment, 2 Mar 2009. 
less protected from gay violence than a 16-year-old girl who has been sexually abused by an actor, who will be tried before the International Criminal Court.

\section{OVERCOMING THE TABOO OF MALE VICTIMS OF SEXUAL VIOLENCE}

It is a fact that men and boys become targets of sexual violence or other massive violations during armed conflicts, but that has received little attention from international community over time ${ }^{40}$. Indeed, men's sexual targeting is not only rare, but is a common feature of all armed conflicts, whether sporadically or systematically. There are many reports that show the intensity and frequency of the phenomenon. Investigations by the United Nations Commission of Experts and the ICT for the Former Yugoslavia, for example, reveal a multitude of cases of men rape in the Former Yugoslavia ${ }^{41}$, as well as the ICC investigations in the Central African Republic. Violence, such as blows and electric shocks in men's genital areas, were also observed in Bosnia, Kosovo, Northern Ireland and Sri Lanka, while forced nudity often accompanied by sexual threats, was recorded in Abu Ghraib. Indeed, the fact that US military personnel harassed sexually imprisoned men in Abu Ghraib Prison in Iraq in 2003-2004 is fact substantiated by disciplinary and judicial investigations.

Recent conflicts confirm the existence and intensity of the phenomenon. In August 2015 a report by the United Nations Independent Investigation Commission in Syria reveals the sexual violence suffered by not only women but also male prisoners with recorded rape cases ${ }^{42}$. A previous report in the country in February 2013 looked at various reports of sexual violence against male and female detainees in detention facilities as a means of posting information, humiliation and punishment ${ }^{43}$. Boys and men in custody were raped and electrocuted in their genital areas with naked wires or burned with cigarettes, lighters or molten plastic ${ }^{44}$.

In addition, Government forces have used sexual violence as a method of coercion, with the detention and rape of male and female family members ${ }^{45}$, in order to force men to fight with anti-forces to surrender. Still, men's victimization remains the least welldocumented, or narrowly marginalized in the literature. In the words of the United Nations Office for the Coordination of Humanitarian Affairs (OCHA), “(...) there is an extremely limited understanding and knowledge of sexual violence against men and boys in humanitarian and research community conflicts (...)" ${ }^{36}$. All this despite the fact that

\footnotetext{
${ }^{40}$ SIVAKUMARAN S., "Sexual violence against men in armed conflict", in European Journal of International Law, 2007, pp. 254.

${ }^{41}$ LEWIS D.A., "Unrecognized victims: Sexual violence against men in conflict settings under international law", in Wisconsin Journal of International Law, 2009, pp. 24ss.

${ }^{42}$ MUDGWAY C., "Sexual exploitation by UN peacekeepers: the "survival sex” gap in international human rights law”, in The International Journal of Human Rights, 2017.

${ }^{43}$ Report of the independent international commission of inquiry on the Syrian Arab Republic, Human Rights Council, A/HRC/22/59, 5 February 2013, para. 107.

${ }^{44}$ Report of the Independent International Commission of Inquiry on the Syrian Arab Republic, Human Rights Council, A/HRC/30/48, 13 August 2015, pag. 13.

${ }^{45}$ MANIVANNAN A., "Seeking justice for male victims of sexual violence in armed conflicts", in New York University of Journal of International Law and Politics, 2014, pp. 638ss.

${ }^{46}$ UN OCHA discussion paper "The Nature, Scope and Motivation for Sexual Violence Against Men and Boys in Armed Conflict, June 2008, pag.
} 
sexual violence against men is directed against male and social identity, leaves long-term psychological consequences for the victim ${ }^{47}$. But with the psychological consequences, survivors experience post-traumatic disorder and intense feelings of shame, guilt, anxiety and emotional desensitization. The factors that sexual violence against men is an overlooked concept are many: lack of logging, lack of localization, lack of legal framework as well as focus on sexual violence against women ${ }^{48}$. Lack of recording of incidents and inability to understand and deal with sexual violence against men. In fact, male victims of sexual violence significantly fail to report their victimization "because of the combination of shame, confusion, fear and stigma" 49 . This sense of shame or responsibility following an incident of sexual violence can cause the victims to remain silent because of the fear of ostracism or alienation from their communities. Also, male victims are even more reluctant to publicize the sexual violence they have suffered during the war than peacetime, as they may feel they have failed to stand up to the cultural norms

\footnotetext{
${ }^{47}$ RUSSELL W., "Sexual violence against men and boys", in Forced Migration Review, 2007, pp. 22, 23. ${ }^{48}$ SIVAKUMARAN S., "Male/Male rape and the "taint" of homosexuality", in Human Rights Quarterly, 2005, pp. 1288ss

${ }^{49}$ O'CONNELL J., "Gambling with the psyche: Does prosecuting human rights violators console their victims?”, in Harvard International Law Journal, 2005, pp. 312ss.
} 
of manhood ${ }^{50}$, aggression $^{51}$ and of protection ${ }^{52}$, intensified in times of armed conflict ${ }^{53}$. In addition, male victims may even fail to recognize the fact that they have been victimized because there may be an established cultural and social belief that men can not

${ }^{50}$ NÍ AOLÀIN F.et al., On the frontlines: Gender, war, and the post-conflict process, Oxford University Press, 2011, pp. 49-55.

${ }^{51}$ TRAHAN J., "The Rome Statute's amendment on the crime of aggression: Negotiations at the Kampala Review Conference", in International Criminal Law Review, 2011, pp. 49ss. VAN SCHAAK B., "Negotiating at the interface of power and law: The crime of aggression", in Columbia Journal of Transnational Law, 2011, pp. 506ss. AMBOS K., "The crime of aggression after Kampala", in German Yearbook of International Law, 2010, 478, 501-504. CLARK R.S., "Amendments to the Rome Statute of the International Criminal Court considered at the first review Conference on the Court, Kampala, 31 May11 June 2010", in Goettingen Journal of International Law, 2010, pp. 690ss. BARRIGA S., GROVER L., "A historic breakthrough on the crime of aggression", in American Journal of International Law, 2011, pp. 518ss. GLENNON M., "The blank-prose crime of aggression", in Yale Journal of International Law, 2010, pp. 71-102. HEINSCH R., "The crime of aggression after Kampala: Success or burden for the future?", in Goettingen Journal of International Law, 2010, 715-740. VON BRAUN L., MICUS A., "Judicial independence at risk: Critical issues regarding the crime of aggression raised by selected human rights organizations", in Journal of International Criminal Justice, 2012, pp. 112ss. FAIRLIE M.A., "The United States and the International Criminal Court post-Bush: A beautiful courtship but an unlikely marriage", in Berkeley Journal of International Law, 2011, pp. 530ss. WEISBORD N., "Conceptualizing aggression", in Duke Journal of Comparative International Law, 2009. WERLE J., Völkerstrafrecht, ed. M. Siebeck, 2012, pp. 610ss. KEMP G., Individual criminal liability for the international crime of aggression, Cambridge University Press, 2017. DINSTEIN Y., War, aggression and self-defence, Cambridge University Press, 2011. VEST H., Völkerrechtsverbrechen verfolgen. Ein abgestuftes Mehrebenenmodell systemischer Tatherrschaft, C.H. Beck, 2011. ZIMMERMANN A., "Amending the amendment provisions of the Rome Statute", in Journal of International Criminal Justice, 2012, pp. 210ss. POLITI M., "The ICC and the crime of aggression. A dream that came through and the reality ahead", in Journal of International Criminal Justice, 2012, pp. 268ss. REISINGER CORACINI A., "The International Criminal Court's exercise of jurisdiction over the crime of aggression-at Least...in reach...over some", in Goettingen Journal of International Law, 2010, pp. 748-788. MANSON R.L., "Identifying the rough edges of the Kampala compromise", in Criminal Law Forum, 2010, pp. 418s. SMALENBACH S., "Das Verbrechen der Aggression vor dem Internationalen Strafgerichtshof: Ein politischer Erfolg mit rechtlichen Untiefen", in Jurist Zeitung, 2010, 745-748. KRESS C., VON HOLTZENDORFF L., "The Kampala compromise on the crime of aggression", in Journal of International Criminal Justice, 2010, pp. 1195-1206.

${ }^{52}$ See ex multis: KRESS C., BARRIGA S., The crime of aggression, Cambridge University Press, 2017. SCHEFFER D., "The complex crime of aggression under the Rome Statute", in Leiden Journal of International Law, 2010, pp. 898ss. MCDOUGALL C., The crime of aggression under the Rome statute of the International Criminal Court, Cambridge University Press, 2013. SAYAPIN S.A., The crime of aggression in international criminal law. Historical development, comparative analysis and present State, ed. Springer, 2014. HAJDIN N., "The nature of leadership in the crime of aggression The ICC's new concern?", in International Criminal Law Review, 2017, pp. 545ss. GILLETT M., "The anatomy of an international crime aggression at the International Criminal Cour"t, in International Criminal Law Review, 2013, pp. 832ss. DE RUITER D., VAN DER WOLF D., Aggression and international criminal law, Wolf Legal Publishers, 2011. TRAHAN J., "From Kampala to New York. The final negotiations to activate the jurisdiction of the International Criminal Court over the crime of aggression", in International Law Review, 2018. GALÁN A., STONE J., "Aggression and the future of the International Criminal Court", in International Law Review, 2018. KRESS C., "On the activation of ICC jurisdiction over the crime of aggression", in Journal of International Criminal Justice, 2018. GALÁN J.S., "Aggression and the future of the International Criminal Court", in International Criminal Law Review, 2018, pp. 306ss. DANNENBAUM T., The crime of aggression, humanity and the soldier, Cambridge University Press, 2018. ${ }^{53}$ SIVAKUMARAN S., Prosecuting sexual violence against men and boys, in DE BROUWER A.M. et al. (eds.), Sexual violence as an international crime: Interdisciplinary approaches, ed. Intersentia, 2013, pag. 82. 
be hurled at the same time that many societies regard sexual intercourse as a homosexual act, irrespective of any elements of coercion or violence that may coexist.

Pauline Oosterhoff, however, has pointed out that the main factor in failing to recognize men as victims of sexual torture is the delay in institutions to recognize that men are actually victims of sexual violence ${ }^{54}$. The stereotypes that men are perpetrators and women victims play an important role, and indeed cultural barriers to the recognition of male and male sexual abuse are profound, leading to a systematic absence of a census of these incidents by researchers and a special study of sexual violence against men. This in turn highlights an additional problem with regard to male victimization: it shows that a dominant gender perspective on the role of women and men during the war prevents researchers and designers political analysis of the issue of sexual violence in time of war ${ }^{55}$.

In addition, both researchers and medical or humanitarian staff often believe that men are not susceptible to sexual abuse, with little attention being paid to signs of abuse, which in the case of women would be considered more carefully ${ }^{56}$. While there may be adequate information and incident reporting, medical staff often tend to misrepresent sexual violence against men as non-sexual abuse ${ }^{57}$. Even though there are instructions to deal with such incidents, many doctors, counselors and humanitarian staff are not trained to look for or recognize signs of sexual violence among men, focusing mainly on finding similar situations experienced by women and men, such as penetrating rape $\mathrm{e}^{58}$. In addition to this, the fact that humanitarian and human rights practitioners have openly expressed their desire to focus exclusively on women victims in order to save resources, since the response structures have in fact focused mainly on recording and addressing the victimization of women ${ }^{59}$.

A very important element, most of which is neglected by researchers, is the interconnection of sexual violence against men with that of women ${ }^{60}$. For example, the Bemba case before the ICT for Rwanda demonstrates haw the rape of the male head of the family was intertwined with the rape of their two daughters, most likely to reinforce the perpetrators of the manifestation of sovereignty over the whole family ${ }^{61}$. Sivakumaran argues that the link between the two forms of sexual violence requires that they be subjected to such analysis because "the dynamics, construction of stereotypes of manhood

\footnotetext{
${ }^{54}$ OOSTERHOFF O., "Sexual torture of men in Croatia and other conflict situations: an open secret", in Reproductive Health Matters, 2004, pp. 68ss.

${ }^{55}$ COHEN D.C. et al, Wartime sexual violence: Misconceptions, implications, and ways forward, Washington DC, United States Institute of Peace, February 2013, pp. 7.

${ }^{56}$ SIVAKUMARAN S., "Sexual violence against men in armed conflicts", in European Journal of International Law, 2007, pp. 256ss.

${ }^{57}$ MANIVANNAN A., "Seeking justice for male victims of sexual violence in armed conflicts", in International Law and Politics, 2014, pp. 654ss.

${ }^{58}$ LANGSRON L., "No penetration-and it's still rape”, in Pepperdine Law Review, 1999, pp. 6ss, in particular concentrated on the american legislation of penetration as a crime according to the jurisprudence. ${ }^{59}$ WILLIAMS S., OPDAM J., "The unrealised potential for transformative reparations for sexual and gender-based violence in Sierra Leone,” in The International Journal of Human Rights, 2017, pp. 1284ss. ${ }^{60}$ OOSTERVELD V., "Sexual violence against men and boys in armed conflict or mass atrocity: Addressing a gendered harm in international criminal Tribunals”, in Journal of International Law and International Relations, 2014, pp. 118ss. ERIKSSON BAAZ M., STERN M., The complexity of violence: A critical analysis of sexual violence in the Democratic Republic of Congo, Nordiska Afrikaininstitutet and Sida, 2010, pp. 7-14, 41-50.

${ }^{61}$ UN OCHA Research Meeting, 26 June 2008, pag. 4.
} 
and femininity involved are similar”62. Both forms of sexual violence are part of the gender dimension of violence in armed conflict, and increased attention can lead to a broader understanding of the role of men and women in armed conflict and therefore to a more effective response to sexual violence in general ${ }^{63}$. Carpenter also emphasizes that the recognition and care of survivors of sexual violence can also lead to their participation in tackling the causes and consequences of sexual violence against women ${ }^{64}$.

\section{IV.LEGAL AND JUDICIAL VACUUM IN VIOLENCE AGAINST MEN}

As has been noted, there is not a human rights text relating to sexual violence against men, while sexual violence against women oftentimes referred to the UN decisions, contracts and other sources of general protection of human rights law: “(...) the international instruments containing the most comprehensive and substantive definitions of sexual violence exclude men from the very first page, incorporating and reflecting the assumption that sexual violence is a phenomenon associated only with women and girls (...)"65. Moreover, despite the wealth of information available, male victims are almost totally ignored by the important decisions adopted by the Security Council on sexual violence in armed conflict. With regard to the statutes of international criminal Tribunals, the fact that only the Statute of the Special Court for Sierra Leone and the ICC contains explicit reference to various forms of sexual violence other than rape, such as sexual slavery, forced prostitution and "any other form of sexual violence", is a serious legal issue $^{66}$. This has often forced international criminal Courts to classify sexual violence against men (for example, blows in the genitals), torture, forced labor, other inhumane acts, cruel and inhuman treatment as persecution etc., the Courts have made remarkable progress in their case-law on these crimes, and although in Rwanda, Former Yugoslavia and Sierra Leone, sexual violence against men was recorded and acknowledged. Moreover, by 2010, there was no case in any criminal Court focusing exclusively on male sexual violence.

In a total of 80 indictments for sexual violence, only 18 of them had corresponding accusations for male victims, and in three cases that could only focus on sexual violence against men, they did not even lead to charges of sexual violence ${ }^{67}$. As noted, however, the ICT Statute for Former Yugoslavia already has an extremely expanded list of crimes of sexual violence, including forced sterilization, which crime elements define as "deprivation of biological reproductive capacity". Indeed, under this broad definition could be the most frequent incidents of sexual violence against men such as genital mutilation, sexual torture, and the ICT for the Former Yugoslavia will be able to issue a

\footnotetext{
${ }^{62}$ CARPENTER R.C., "Recognizing gender-based violence against civilian men and boys in conflict situations", in Security Dialogue, 2006, pp. 98-99.

${ }^{63}$ STEMPLE L., "Male rape and human rights", in Hasting Law Journal, 2009, pp. 619ss.

${ }^{64}$ See the statute of the Special Tribunal for Sierra Leone, art. 2 (g), and the statute of the International Criminal Court, articles: 7 (1), 8 (2)(b)(xxii), (2)(e)(vi).

${ }^{65}$ Simić Trial Judgment, paras. 697, 698, 771. See also: SIVAKUMARAN S., "Lost in translation: UN responses to sexual violence against men and boys in situations of armed conflict", in International Review of the Red Cross, 2010, pp. 259, 264ss.

${ }^{66}$ NIGGLI M.A., HEIMGARTNER ST., Internationales Strafrecht, Helbing Lichtenhahn, 2015.

${ }^{67}$ Prosecutor v. Mejakic, Case No. IT-95-4, Initial Indictment 13 February 1995, para. 29.1; Prosecutor v. Mucic, Case No. IT-96-21-T, Judgment, 16 November 1998, para. 1275; Prosecutor v. Naletilic \& Martinovic, Case No. IT-98 34-T, Judgment, 31 March 2003, para. 450.
} 
conviction for the crime against humanity referred to in Article $7(1)(g)^{68}$. It should be noted that the ICC has taken some first steps in this direction by coping with a Court document in Kenya case on sexual violence ${ }^{69}$ against men in the form of forced circumcision and the rape of a man in Bemba case ${ }^{70}$. More specifically, in Bemba case, the Prosecutor's Office included in their accusations rape committed against both women and men, and called not only women victims but also two men in positions of authority who were victims of rape in order to testify at the trial. In Kenyatta case, the Prosecutor's Office included in the allegations acts of forced circumcision and mutilation of the penis of men regarded as supporters of the opposing political party ${ }^{71}$.

The case-law progress that may be made in the context of ICT for Rwanda may also be based on previous case-law of ad hoc criminal Tribunals ${ }^{72}$. The ICT of Rwanda has given such a broad definition of sexual violence, including even acts that do not constitute physical contact ${ }^{73}$. The ICT of Rwanda has also recognized that rape and sexual violence can be committed against men and women, although no one in Rwanda has been accused of sexual abuse of men. In conclusion, all the above obstacles, resulting from the socialcultural context of the victims, the lack of understanding, knowledge and recognition of sexual violence against men, the ICC has an excellent opportunity to overcome them, learning from the mistakes of the past. In the recent conflict in Syria, there are extensive reports of incidents of sexual violence against men, particularly in the context of detention. It is an excellent opportunity for the Tribunal, if the Security Council refers the case before it, since Syria has not signed the Rome Statute, to be accused of these crimes ${ }^{74}$.

\section{V.THE NEW POLICY DOCUMENT OF THE ICC PROSECUTOR'S OFFICE: ADDRESSING THE GAPS IN INTERNATIONAL CRIMINAL JUSTICE}

In the wake of the judgment in Prosecutor v. Katanga, whose verdict is the most recent

\footnotetext{
${ }^{68}$ Prosecutor v. Muthaura \& Kenyatta, Case No. 01/09-02/11, Victim's Observations on the "Prosecution's application for notice to be given under Regulation 55 (2) with respect to certain crimes charged, 24 July 2014, para. 14, Prosecutor v. Bemba, Case No. 01/05-01/08, Decision Pursuant to Article 61 (7)(a) and (b) of the Rome Statute on the Charges of the Prosecutor Against Jean-Pierre Bemba Gombo, 15 June 2009, para. 171.

${ }^{69}$ HELLWIG-BÖTE M., "Political bickering over the International Criminal Court: The Case of Kenya, January 2014", Stiftung Wissenschaft Politik, 2015. MUELLER S.D., "Kenya and the International Criminal Court (ICC): Politics, the election and the law", in Journal of Eastern African Studies, 2014, pp. 5ss. MUKUM MBAKU J., "International justice: The International Criminal Court and Africa, January 2014, Foresight Africa: Top Priorities for the Continent in 2014 “, The Brookings Africa Growth Initiative, 2015.

${ }^{70}$ Prosecutor v. Bemba, Public Redacted Version of the Amended Document containing the charges filed on 30 March,2009, Case No. ICC-01/05-01/08-395-Anx3, 30 March 2009.

${ }^{71}$ Prosecutor v. Kenyatta, Public Redacted Version of the Corrigendum of the Second Updated Document Containing the Charges, ICC-01/09-02/11-732-AnxA-Corr-Red, 10 May 2013, pag. 34.

${ }^{72}$ BRADY H., "The power of precedents: using the case law of the ad hoc international criminal Tribunals and hybrid Courts in adjudicating sexual violence and gender-based crimes at the ICC”, in Australian Journal of Human Rights, 2012.

${ }^{73}$ ZAWATI H.M., "Impunity or immunity: Wartime male rape wants sexual torture as a crime against humanity", in Torture, 2007, pp. 34ss.

${ }^{74}$ Women's Initiatives for Gender Justice, Statement of Women's Initiatives for Gender Justice, Appeals Withdrawn by Prosecution and Defence, The Prosecutor vs. Germain Katanga, 26 June 2014. WOLFE L., "Blind spot: Why do convictions for the world's worst crimes neglect survivors of rape?”, in Foreign Policy, 12 March 2014.
} 
example of the Prosecutors Office failure to secure conviction for sexual or gender-based crimes $^{75}$, the ICC Prosecutor's Office has released a Policy Paper on Sexual and GenderRelated Crimes, which confirms the commitment the latter to prosecute these crimes $^{76}$. This document, as will be demonstrated by the following analysis, recognizing the challenges faced by international criminal justice with regard to these crimes, sets out objectives and policies to overcome these deficiencies and to develop the approach of the Court in regards to sex and crimes related to it, in the application of international criminal law.

The Policy Document, which is the result of a two-year internal and external consultation process ${ }^{77}$, is an important public commitment by the Prosecutor that its Office will address holistically the investigation and prosecution of gender-based crimes ${ }^{78}$. The perspectives for tackling gender and sexual violence will include gender mainstreaming across the Office's range of competences, from the analysis of criminal standards to administrative structures, particularly within the context of "gender-specific dynamics in a specific context”. This will result in maximizing dissuasive effect, challenging the gender-based hierarchy, and justifying the experiences lived people who have been victims.

In his preamble, he goes on to define gender-based crimes by defining them as "those committed against persons, whether men or women, because of their gender and/or socially-constructed gender roles. Gender-related crimes are not always manifested as a form of sexual violence. They may include non-sexual attacks on women and girls, men and boys because of their sex (...)" ${ }^{\text {79 }}$. Below, it does not refer to the gender dimension adopted by the policy document. Apart from the importance of the distinction between the social and biological sex proposed by the Document, these reports are of particular importance, including men, as an important step in the fight against the impunity of sexual violence. However, violence against men has traditionally ignored and is therefore largely unpunished.

The Document begins by reaffirming once again that it "pays particular attention" to sexual and gender violence. He adds not that the Prosecutor's Office believes that all crimes of the ICC's jurisdiction ${ }^{80}$ are likely to be gendered. In this context, commit these crimes by persecuting them whenever they can be taught sufficient evidence to allow it. Thus, whenever he judges that "there is sufficient evidence to support (...) the charges" for sexual and gender-based crimes, the Prosecutor's office assures that he will be

\footnotetext{
${ }^{75}$ PÉREZ-LEÓN-ACEVEDO J.P., "The Katanga reparation order at the International Criminal Court developing the emerging reparation, practice of the Court", in Nordic Journal of Human Rights, 2018.

${ }^{76}$ International Criminal Court, The Office of the Prosecutor, Policy on Sexual and Gender- Base Crimes, June 2014.

${ }^{77}$ FATOU BENSOUDA, The Investigation and prosecution of sexual and gender-based crimes: reflections from the Office of the Prosecutor, The Hague Academy of International Law Advanced Course on International Criminal Law-Special Focus: Gender Justice, Keynote Speech, 24 August 2015, pp. 4ss.

${ }^{78}$ BENSOUDA F., "Reflections from the International Criminal Court Prosecutor", in Case Western Journal of International Law, 2012, pp. 506ss.

${ }^{79}$ WACHALA K., "The tools to combat the war on women's bodies: Rape and sexual violence against women in armed conflict”, in The International Journal of Human Rights, 2012.

${ }^{80}$ YANG G., International Criminal Court: A judicial guarantee for international peace and security, in BERGSMO M., LING Y., State sovereignty and international criminal law, Torkel Opshal Academic Epublisher, 2012, pp. 98ss. YASUAKI O., International law in a transcivilizational world, Cambridge University Press, 2017.
} 
prosecuted. It will prosecute sexual and gender-based crimes "as crimes by itself" as well as "other crimes of ICC jurisdiction, for example by persecuting rape as torture, persecution and genocide (...) it stresses the importance of Article 21(3) of the Statute because it requires the application of the Statute and its interpretation to be in accordance with internationally recognized human rights, without any discrimination on grounds of among other things gender or other circumstances (...)" 81 .

An important recognition of the new policy paper is the adoption of a new approach to evidence. As discussed above, accusations of sexual violence before international criminal trials have often failed, not because of problems related, for example, to the evidence of international crimes or to the choice of the appropriate form of liability of the accused. It is without question true that researchers and prosecutors face particular challenges when dealing with victims and witnesses of sexual violence ${ }^{82}$, but these can be addressed through appropriate training and specialization. The ICTR Review Committee's conclusion on sexual violence is that low levels of convictions for sexual violence crimes in Rwanda Court are due not to the lack of evidence-as rape victims and witnesses were available-but more to lack of understanding, specialization and training with regard to obtaining the necessary evidence to support its decision ${ }^{83}$. Experience from other criminal Courts has shown that the fundamental issue is the ability to recognize sexual violence, the determination and approximation of victims with respect and discretion, the way in which interview and the taking evidence are based, the foundation and substantiation of the case and the choice of the most appropriate form of liability, as well as the presentation of the case to the judges, who will fully judge the criminal responsibility.

The new political Document seems to have incorporated these fundamental issues. Some of the most important areas of reform, as defined by the policy document, relate to the overall strategy of investigation and prosecution, which has the potential to positively influence the Prosecutor's work, even in non-sexual cases. An example is the abandonment of the focused research strategy for the sake of "more in-depth openness" (...) so that more evidence from different sources can be collected (...)”. This emphasis on the different and new sources of evidence reflects the challenge of the Prosecutor's Office regarding the extent to which this should be based so much on witness testimonies. In the speech of Prosecutor Fatou Bensouda in the presentation of the Policy Document, he said that the Prosecutor's Office: “(...) has decided to change the strategy not only by looking at witness statements but also by documenting evidence such as hospital records and using forensic strategies investigations as a new way of collecting the evidence we need (...)" ${ }^{84}$.

The Policy paper states that: the office is aware that victims of sexual and gender violence may face additional risks of discrimination, social stigma, exclusion from their families and the community, bodily harm, or other retaliation, In order to minimize their

\footnotetext{
${ }^{81}$ BOSLY H., VANDERMEERSCH D., Gènocide, crimes contre l'humanitè et crimes de guerre face à la justice, ed. Bruylant, 2012.

${ }^{82}$ United Kingdom: Foreign and Commonwealth Office, International Protocol on the Documentation and Investigation of Sexual Violence in Conflict, June 2014.

${ }^{83} \mathrm{BIANCHI}$ L., The prosecution of rape and sexual violence: Lessons from prosecution at the ICTR, in DE BROUWER A.M. et al. (eds.), Sexual violence as an international crime: Interdisciplinary approaches, ed. Intersentia, 2013, pp. 125ss.

${ }^{84}$ NIAHM H., La lutte continue: Investigating and prosecuting sexual violence at the ICC, in STAHN C., The law and practice of the International Criminal Court, Oxford University Press, 2015, pp. 831ss.
} 
exposure and potential recurrence, the Office will strengthen its efforts to collect other forms of evidence, where available, including empirical surveys and reports, and other reliable data provided by States, the United Nations, transnational and non-governmental organizations, and other trusted sources. However, this reference is of particular value for another reason. Recognition by Prosecutor's Office of the likelihood that the victim will experience the trauma again during his testimony signals the Office's greatest turn in paying particular attention to the individual "personal circumstances" of the victims ${ }^{85}$. It adopts a model centered on the victim, sensitized to the needs of the latter ${ }^{86}$. It therefore recognizes that one instrumental focus of the victims jeopardizes the provision of justice to victims of sexual and gender-based crimes and undermines the possible remedial value of persecution ${ }^{87}$. Evidence of difficulties will also be addressed through increased use of gradual prosecutions, investigations of which will start from the lowest to the highest level, and the cultivation of costly and trustworthy witnesses.

However, the Policy Document recognizes another factor that has been dealt with by international criminal justice and has even contributed to the forfeiture or inability to justify the charges. These are forms of responsibility. In the Policy Document, Prosecutor's Office declares itself ready to reinforce the possibility of issuing convictions against the administrative and military superiors and to accuse the basis both of Article

\footnotetext{
${ }^{85}$ MCDERMOTT Y., SCHABAS W.A., Ashgate research companion to international criminal law. Critical perspectives, ed. Routledge, 2016.

${ }^{86}$ The Office of The Prosecutor of the ICC, "Policy Paper on Sexual and Gender Based Crimes: ICC Outlines Policies to Improve Prosecutorial Outcomes, Recent Policy Paper”, in Harvard Law Review, 2014, pp. 799ss.

${ }^{87}$ MOUTHAAN S., "Victim participation at the ICC for victims of gender-based crimes: A conflict of interest?”, in Cardozo Journal of International and Comparative Law, 2013, pp. 619ss.
} 


\begin{abstract}
${ }^{88}$ See in argument: Prosecutor v. Katanga and Ngudjolo, ICC PT. Ch. I, ICC-01/04-01/07-717, 30 September 2008, paras. 515-518). The Pre-Trial Chamber set forth two objective elements: “(...) 1) the existence of a common plan between two or more persons; and 2) the coordinated essential contribution made by each co-perpetrator that results in the realisation of the objective elements of the crime. The Lubanga Trial Chamber then, following the reasoning set forth by the Pre-Trial Chamber, agreed that under the co-perpetration theory two or more individuals must act jointly within the common plan, which must include "an element of criminality" (...)“. (Prosecutor v. Lubanga, ICC PT. Ch. I, Decision on the Confirmation of Charges , ICC-01/04-01/06-803, 29 January 2007, para. 343). The Pre-Trial Chamber found that the plan did not need to be specifically directed at the commission of a crime.the Lubanga Trial Chamber did find that it is necessary to prove that if events followed the ordinary course of events, a crime will be committed (Prosecutor v. Lubanga, ICC T. Ch. I, Judgment pursuant to Article 74 of the Statute, ICC-01/04-01/06-2842, 14 March 2012, para. 2984). (Prosecutor v. Lubanga, ICC T. Ch. I, Judgment, ICC01/04-01/06-2842, 14 March 2012, para. 994). In this case the Chamber notes that the Prosecution: “(...) does not have the burden to demonstrate that the contribution of the accused, if taken alone, would have caused the crime. Rather, the Prosecutor must prove mutual attribution, based on joint agreement or common plan. The Majority states that what is decisive is 'whether the co-perpetrator performs an essential role in accordance with the common plan, and it is in this sense that his contribution, as it relates to the exercise of the role and functions assigned to him, must be essential (...)“. (Prosecutor v. Lubanga, ICC T. Ch. I, Judgment, ICC-01/04-01/06-2842, 14 March 2012, para. 1000). In Lubanga case we have seen the Judge Fulford's "dissenting“ reasoning, rectius interpretation. In particular: “(...) a. A plain text reading of Article 25(3)(a) would establish the following elements for coperpetration: The involvement of at least two individuals; b. Coordination between those who commit the offence, which may take the form of an agreement, common plan or joint understanding, express or implied, to commit a crime or to undertake action that, in the ordinary course of events will lead to the commission of the crime; c. A contribution to the crime which may be direct or indirect, provided either way there is a causal link between the individual's contribution and the crime. d. Intent and knowledge, as defined in Article 30 of the Statute, or as "otherwise provided“ elsewhere in the Court’s legal framework (...)“. Judge Fulford was concerned about hypothetical and counterfactual reasoning that would be required by the control theory as applied by the Chamber's approach. Because this control theory requires the "essential contribution " finding, it is necessary to decide if the crime would have still occurred in the absence of the defendant's contribution (...)“. (Prosecutor $v$. Lubanga, ICC T. Ch. I, Judgment, Separate Opinion of Judge Adrian Fulford, ICC-01/04-01/06-2842, 14 March 2012, para. 17). The Chamber concludes: “(...) that "control" over an immediate actor can be exerted by means of an organisation. Since the Article explicitly declares it irrelevant whether the person through whom the crime is committed acts culpably or not, the Chamber here concludes that the 'control' over the immediate actor can be exerted through an organisation. The Chamber notes that, “(...) the cases most relevant to international criminal law are those in which the perpetrator behind the perpetrator commits the crime through another by means of "control over an organization" (...)" (Prosecutor v. Katanga, ICC PT. Ch. I, ICC-01/04-01/07-717, 30 September 2008, para. 498). The Pre-Trial Chamber then goes on to define the necessary elements of an "organisation": “(...) for these purposes: The Chamber finds that the organization must be based on hierarchical relations between superiors and subordinates. The organization must also be composed of sufficient subordinates to guarantee that superiors' orders will be carried out, if not by one subordinate, then by another. These criteria ensure that orders given by the recognized leadership will generally be complied with by their subordinates (...)“. (Prosecutor v. Katanga, ICC PT. Ch. I, ICC01/04-01/07-717, 30 September 2008, para. 512). The Mbarushimana Pre-Trial Chamber commented, with reference to this sub-provision, in its Confirmation of Charges decision that "the application of analogous modes of liability at the ad hoc tribunals suggests that a substantial contribution to the crime may be contemplated" (Prosecutor v. Mbarushimana, PT. Ch. I, Decision on the Confirmation of Charges, ICC01/04-01/10-465-Red, 16 December 2011, para. 279). The Pre-Trial Chamber stated: “(...) the objective and subjective elements required in order to find individual responsibility. The three objective elements were stated as: i) a crime within the jurisdiction of the Court is attempted or committed; ii) the commission or attempted commission of such a crime was carried out by a group of persons acting with a common purpose; and iii) the individual contributed to the crime in any way other than those set out in Article 25(3)(a) to (d) of the Statute. The subjective elements were elaborated as: i) the contribution shall be intentional;
\end{abstract}


and ii) shall either a) be made with the aim of furthering the criminal activity or criminal purpose of the group; or b) in the knowledge of the intention of the group to commit the crime (...)“. (Prosecutor v. Mbarushimana, PT. Ch. I, Decision on the Prosecutor's Application for a Warrant of Arrest against Callixte Mbarushimana, ICC-01/04-01/10-1, 11 October 2010, para. 39). See in argument: WEIGEND T., "Intent, mistake of law, and co-perpetration in the Lubanga Decision on confirmation of charges“, in Journal of International Criminal Justice, 2008, pp. 474ss. SCHABAS W.A., The International Criminal Court, A commentary to the Rome Statute, Oxford University Press, 2008, pp. 424ss. WERLE J., "Individual criminal responsibility in Article 25 ICC Statute“, in Journal of International Criminal Justice, 2007, pp. 954ss. In particular judge Wyngaert stated that: “(...) if the mental element is linked to a contribution towards a broadly defined common plan, as the control theory does, then the connection to the crime might be almost entirely lost. When this happens, we come dangerously close to treating the mode of criminal responsibility as a crime in itself (...)“. Judge Van den Wyngaert (The Prosecutor v. Ngudjolo Chui, ICC, Judgment, (Trial Chamber)), argued that: “(...) the notion of Organisationsherrschaft, control over an organisation, is not consistent with 25(3)(a), which only provides for indirect perpetration through another person, not through an organisation (...)“. See also in argument: YANEV L.D., Theories of co-perpetration in international criminal law, ed. Brill, 2018. MELONI C., Fragmentation of the notion of co-perpetration in international criminal law, in VAN DEN HERIK L., STAHN C. (eds.), The diversification and fragmentation of international criminal law, ed. Brill, 2012, pp. 501-502. According to our opinion there is a possibility that the ICC in the future may apply basic or systemic JCE, or a notion similar to them, if the current interpretation of the Rome Statute changes. Extended JCE cannot, however, be applied. Cfr. JANJAC K., The mental element in the Rome statute of the International Criminal Court, Wolf Legal Publishers, 2013.

${ }^{89}$ Superior responsibility is thus distinct from for example "ordering” under Article 25 which requires the superior to have actively contributed to the crime in question as we can see in Prosecutor v. Bemba, ICC PT Ch. II, Decision Pursuant to Article 61(7)(a) and (b) of the Rome Statute on the Charges of the Prosecutor Against Jean-Pierre Bemba Gombo, ICC-01/05-01/08, 15 June 2009, par. 405). The superior is responsible for: "(...) there will be practical consequences, not only in relation to the stigma attached to a guilty verdict under the doctrine, but also in respect of for example sentencing considerations, evidentiary demands and possibly even the interpretation of the elements of the doctrine. Superior responsibility is a Mode of Participation and the superior in this manner is convicted as a participant in the "principal crime". Superior responsibility shares common feature with other Modes of Participation in that they are accessory to the principal crimes committed by other perpetrator/s. The difference is however that in respect of the other Modes of Participation there needs to be a positive act or, at least, a certain level of contribution to the commission of the principal crime (...) superior responsibility is rather characterised by inaction/nonaction of the superior. Despite this fact, there have been strong proponents for an interpretation of that superior responsibility should be interpreted as a Mode of Participation (...)". Orić Prosecution Appeal Brief, 18 October 2006, par. 162) the criminal responsibility of the superior is limited to his or her own failure to act with regard to, or in relation to, the "principal crime". In accordance with this interpretation, the superior is convicted: "(...) not for the "principal crime”, but merely for his or her own failure to act or. This interpretation does evaluate the level of responsibility, not only to the gravity of the superior's own failure, but also to the gravity of the "principal crime". The Trial Chamber did however stress the connection to the gravity of the principal crime in the following: “(...) the imposition of responsibility upon a commander for breach of his duty is to be weighed against the crimes of his subordinates; a commander is responsible not as though he had committed the crime himself, but his responsibility is considered in proportion to the gravity of the offences committed” (Prosecutor v. Halilović, ICTY T. Ch., 16 November 2005, par. 54) (...) the connection between the responsibility of the superior and the gravity of the "principal crime" is further developed in the Hadžihasanović Appeal Judgment (Prosecutor v. Hadžihasanović (Case No. IT-01-47-A), ICTY A. Ch, Judgment, 22 April 2008, parr. 312-318). According to Fenrick: "(...) the concept "person effectively acting as military commander" may accordingly also include persons who have assumed de facto control over armed forces, armed police units or paramilitary units (FENRICK W., Article 28, in TRIFFTERER O. (ed.), Commentary on the Rome Statute of the International Criminal Court, Nomos Verlagsgesellschaft, Baden-Baden, 1999, pp. 518-520) (...) a person may be accountable under the doctrine of superior responsibility based on "de facto command" finds support in the case law of both the ad hoc Tribunals and the ICC. Representative of this opinion is the following quote from the Čelebići T.Ch.: 
"Formal designation as a commander should not be considered to be a necessary prerequisite for command responsibility to attach, as such responsibility may be imposed by virtue of aperson's de facto , as well as de jure, position as a commander" (Prosecutor v. Mucic et al., ICTY T. Ch., 16 November 1998, par. 370) (...)". The same pronouncement is encapsulated in the following quote from the ICC: "With respect to a "person effectively acting as a military commander", the Chamber considers that this term is meant to cover a distinct as well as a broader category of commanders. This category refers to those who are not elected by law to carry out a military commander's role, yet they perform it de facto by exercising effective control over a group of persons through a chain of command”. Prosecutor v. Bemba, ICC PT Ch. II, 15 June 2009, par. 409. "(...) "authority and control" is a somewhat broader concept than "effective command and control" according to Fenrick: "(...) the definition and the distinction between these terms was addressed by the ICC in the Bemba case, where it was concluded that: "Article 28(a) of the Statute refers to the terms "effective command and control" or "effective authority and control” as applicable alternatives in situations of military commanders strictu sensu and military-like commanders. In this regard, the Chamber considers that the additional words "command" and "authority" under the two expressions has no substantial effect on the required level or standard of "control" (...) in this context, the Chamber underlines that the term "effective command" certainly reveals or reflects "effective authority". Indeed, in the English language the word "command" is defined as "authority, especially over armed forces", and the expression "authority" refers to the "power or right to give orders and enforce obedience” (...)". Prosecutor v. Bemba, ICC PT Ch. II, Decision Pursuant to Article 61(7)(a) and (b) of the Rome Statute on the Charges of the Prosecutor against Jean-Pierre Bemba Gombo, 15 June 2009, parr. 412-413. According to Ambos: “(...) further stresses that "it should be clear now (...) that the "should have known" standard must be understood as negligence and that it, therefore, requires neither awareness nor considers sufficient the imputation of knowledge on the basis of purely objective facts (...) a specific comment as to this point with regard to the Bemba confirmation decision. He thus points out that both of these standards ought to constitute a negligence standard and that it would be beneficial for the ICC to apply a restrictive interpretation of the "should have known"-standard in order to bring it closer in line with the "reason to know" standard (...) the Appeals Chamber recalls that the ICTR Appeals Chamber has on a previous occasion rejected criminal negligence as a basis of liability in the context of command responsibility, and that it stated that "it would be both unnecessary and unfair to hold an accused responsible under a head of responsibility which has not clearly been defined in international criminal law (...)". The Appeals Chamber expressly endorses this view”. Prosecutor v. Blaškić, ICTY A Ch., 29 July 2004, par. 63. In the Orić case: “(...) the Trial Chamber furthermore formulated a normative yardstick in order to measure whether the superior has fulfilled his or her duty to prevent: "first, as a superior cannot be asked for more than what is in his or her power, the kind and extent of measures to be taken ultimately depend on the degree of effective control over the conduct of subordinates at the time a superior is expected to act; second, in order to be efficient, a superior must undertake all measures which are necessary and reasonable to prevent subordinates from planning, preparing or executing the prospective crime; third, the more grievous and/or imminent the potential crimes of subordinates appear to be, the more attentive and quicker the superior is expected to react; and fourth, since a superior is duty bound only to undertake what appears appropriate under the given conditions, he or she is not obliged to do the impossible (...)”. Prosecutor v. Orić, ICTY T Ch, Judgment, 30 June 2006, par. 329: "(...) the Čelebići, Musema, Bagilishema cases expressed similar views. "[I]t is (...) the Trial Chamber's conclusion that a superior, whether military or civilian, may be held liable under the principle of superior responsibility on the basis of his de facto position of authority (...) the principle of superior responsibility to be applicable, it is necessary that the superior have effective control over the persons committing the underlying violations of international humanitarian law, in the sense of having the material ability to prevent and punish the commission of these offences (...)”. Prosecutor v. Mucic et al., ICTY T. Ch., Judgment, 16 November 1998, parr. 377-378: "(...) it is also significant to note that a civilian superior may be charged with superior responsibility only where he has effective control, be it de jure or merely de facto, over the persons committing violations of international humanitarian law (...)”. Prosecutor v. Musema, ICTR T Ch., Judgment, 27 January 2000, par. 141: “(...) the effective control test applies to all superiors, whether de jure or de facto , military or civilian”. Prosecutor v. Bagilishema, ICTR A Ch., Judgment, 3 July 2002, par. 50. Also see: AMBOS K., Individual criminal responsibility, in TRIFFTERER O. (ed.), Commentary on the Rome Statute of the International Criminal Court: Observers' Notes, Article by Article, 2nd ed., C.H. Beck/Hart/Nomos, 2008, pp. 795-843. AMBOS K., "Critical Issues in the Bemba decision", 
Office will specifically ensure that it will make more extensive use of the provisions on seniority liability, in accordance with Article 28, “(...) in order to encourage military commanders and civilian officers to effectively deal with the commission of these crimes by their forces or subordinates" 90 . The Prosecutor's Office also makes clear that it will pay particular attention to the possible use of evidence models to substantiate the accuser's knowledge or awareness of crimes of sexual and gender-based violence, in accordance with Article 30 (mental element) ${ }^{91}$.

in Leiden Journal of International Law, 2009, pp. 715-26. NYBONDAS M.L., Command responsibility and its applicability to civilian leaders, ed. TMC Asser Press, 2010. ARCHIBUGI D., PEASE A:, Crime and global justice: The dynamics of international punishment, ed. Polity, 2018. DONDÉ MATUTE J., "Responsabilidad penal internacional: Los nuevos escenarios dogmàticos", in Anuario Mexicano de Derecho Internacional, 2018.

${ }^{90}$ HOYLE L., "Command responsibility-A legal obligation to deter sexual violence in the military", in Boston College International \& Comparative Law Review, 2014, pp. 354ss.

${ }^{91}$ See in particular: Prosecutor v. Katanga and Ngudjolo Chui, ICC PT. Ch., Decision on the Confirmation of Charges, ICC-01/04-01/07-717, 30 September 2008, para. 529; Prosecutor v. Bemba Gombo, ICC PT. Ch., Decision on the Confirmation of Charges, ICC-01/05-01/08-424, 15 June 2009, para. 356: "(...) article 30 of the ICC Statute would not accommodate any standard of mens rea below the threshold of knowledge of result in terms of practical certainty (...) in this sense: Prosecutor v. Bemba, ICC PT. Ch., Decision Pursuant to Article 61(7)(a) and (b) of the Rome Statute on the Charges of the Prosecutor Against JeanPierre Bemba Gombo, ICC-01/05-01/08-424, 15 June 2009, paras. 359ss; Prosecutor v. Lubanga, ICC T. Ch., Judgment pursuant to Article 74 of the Statute, ICC-01/04-01/06-2842, 14 March 2012, para. 1011; Prosecutor v. Lubanga, ICC A. Ch., Judgment on the Appeal of Mr. Thomas Lubanga Dyilo against his conviction, ICC-01/04-01/06-A-5, 1 December 2014, paras. 441; Prosecutor v. Lubanga, ICC PT. Ch., Decision on the Confirmation of Charges, ICC-01/04-01/06-803-t, 29 January 2007, paras. 352; Prosecutor v. Katanga and Ngudjolo Chui, ICCPT. Ch., Decision on the Confirmation of Charges, ICC-01/04-01/07717, 30 September 2008, para. 251 fn. 329: "(...) the Pre-Trial Chamber added the following specification: [t]he Chamber considers that in the latter type of situation, two kinds of scenarios are distinguishable (...) if the risk of bringing about the objective elements of the crime is substantial (that is, there is a likelihood that it "will occur in the ordinary course of events"), the fact that the suspect accepts the idea of bringing about the objective elements of the crime can be inferred from: i. the awareness by the suspect of the substantial likelihood that his or her actions or omissions would result in the realisation of the objective elements of the crime; and ii. the decision by the suspect to carry out his or her actions or omissions despite such awareness (...) ICC argued that: (w)ith respect to dolus eventualis as the third form of dolus, recklessness or any lower form of culpability, the Chamber is of the view that such concepts are not captured by Article 30 of the Statute. This conclusion is supported by the express language of the phrase "will occur in the ordinary course of events", which does not accommodate a lower standard than the one required by dolus directus in the second degree (oblique intention) (...)"; Prosecutor v. Bemba, ICC PT. Ch., Decision Pursuant to Article 61(7)(a) and (b) of the Rome Statute on the Charges of the Prosecutor Against JeanPierre Bemba Gombo, ICC-01/05-01/08-424, 15 June 2009, para. 360), that: "(...) the Pre-Trial Chamber concluded therefore that "the suspect could not be said to have intended to commit any of the crimes charged, unless the evidence shows that he was at least aware that, in the ordinary course of events, the occurrence of such crimes was a virtually certain consequence of the implementation of the common plan (...)" (Prosecutor v. Bemba, ICC PT. Ch., Decision Pursuant to Article 61(7)(a) and (b) of the Rome Statute on the Charges of the Prosecutor Against Jean-Pierre Bemba Gombo, ICC-01/05-01/08-424, 15 June 2009, para. 368; Prosecutor v. Lubanga, ICC T. Ch., Judgment pursuant to Article 74 of the Statute, ICC-01/0401/06-2842, 14 March 2012, para. 1012, according to the ultimate judgment: "(...) due to the cumulative reference to "intent and knowledge" in Article 30(1) ICC Statute, the requirement of knowledge in relation to result should apply even to an agent who clearly wanted to bring about the result pursuant to the first alternative of Article 30(2)(b) ICC Statute. Finnin illustrates the practical outcome of this by inviting the reader to consider the case of an accused who plants an improvised explosive device (or 'IED', which have a notoriously low success rate), which he or she intends to initiate remotely when civilians come within range. It is the perpetrator's conscious object to kill those civilians; however, unless it could be shown that 
The Prosecutor also stated that he would "attribute different forms of liability in an auxiliary manner where appropriate”. In the Policy Document, the Prosecutor's Office also states that it is ready to deliver charges based on the range of forms of participation allowed by the Rome Statute. When also choosing to bring charges, Prosecutor's Office will do so cumulatively and additionally to reflect the seriousness and multidimensionality of these crimes.

Regarding the latter, it is worthwhile to make some remarks. The ICT for the Former Yugoslavia has assessed the value of cumulative accusations for the same criminal behavior. As has been pointed out, the logic of this practice is that, before all the evidence is presented, it is not possible to determine with certainty which of the accusations will ultimately prove. The Court is in a position to assess which accusations will be held, based on the adequacy of the evidence ${ }^{92}$.

As has also been pointed out by the international criminal for the Former Yugoslavia Court of Appeal, "multiple convictions serve to record the full guilt of a particular defendant or provide a full picture of his criminal behavior" ${ }^{93}$. However, redress, when commenting on the draft Policy Paper, criticized this by pointing to the possible unfair treatment of the accused in cases of decisions on cumulative charges for criminal behavior. In particular, it referred to the principle that the total penalty should reflect all the culpable conduct, also indicating Rule 55 of ICC $^{94}$. Noting that witness testimony is often

\footnotetext{
he or she knew (at the time the device was initiated) that the device would explode successfully and thereby result in the death of those civilians, the perpetrator would not satisfy this gradation of intent (...) This obviously represents an unexpected and undesired consequence of the conjunctive "intent and knowledge" wording of Article 30 (...)". Also see: BADAR M.E, "Dolus eventualis and the Rome Statute without it?", in New Criminal Law Review, 2009, pp. 436ss. BADAR, The concept of mens rea in international criminal law. The Case for a unified approach, Hart Publishing, 2013. BADAR M., HIGGINS N., General principles of law in the early jurisprudence of the ICC, in MARINIELLO T. (ed.), The International Criminal Court in search of its purpose and identity, ed. Routledge, 2014. BADAR M, PORRO S., Rethinking the mental elements in the jurisprudence of the ICC, in STAHN C.(ed.), The law and practice of the International Criminal Court, Oxford University Press, 2015. CASSESE A. (ed.), International criminal law, Oxford University Press, 2013. GIL GIL A., "Mens rea in co-perpetration and indirect perpetration according to article 30 of the Rome Statute. Arguments against punishment for excesses committed by the agent or the co-perpetrator", in International Criminal Law Review, 2014, pp. 85ss. HELLER K.J., The Rome Statute of the International Criminal Court, in HELLER J., DUBER M.D. (eds.), The Handbook of comparative criminal law, Stanford Law Books, Stanford, 2011, pp. 594ss. PORRO S., Risk and mental element: An analysis of national and international law on core crimes, ed. Nomos, 2014. WERLE J., JESSBERGER F., Principles of international criminal law, 3rd ed., Oxford University Press, 2014, pp. 795ss. FINNIN S., "Mental elements under article 30 of the Rome statute of the International Criminal Court. A comparative analysis", in International \& Comparative Law Quarterly, 2012, pp. 328ss.

${ }^{92}$ Čelebići Appeal Judgment, Case No. IT-96-21-A, 20 February 2001, para. 400, Kupreškić et al. Appeal Judgment, Case No. IT-95-16-A, 23 October 2001, para. 385; Kunarac et al. Appeal Judgment, Case No. IT-96- 23\&IT-96-23/1-A, 12 June 2002, para. 167; Naletilić \& Martinović Appeal Judgment, Case No. IT98-34-A, 3 May 2006, para. 103; Galić Appeal Judgment, Case No. IT-98-29-A, 30 November 2006, para. 161.

${ }^{93}$ Naletilić \& Martinović Appeal judgment, Case No. IT-98-34-A, 3 May 2006, para. 585 quoting Kunarac et al. Appeal judgment, para. 169 (citing the Partial Dissenting Opinion of Judge Shahabuddeen in the Jelisić Appeal judgment, para. 34). BRIMA et al., Appeal judgment, Case No. SCSL-2004-16-A, 22 February 2008, para. 215.

${ }^{94}$ In pag. 4-5 referred that Regulation 55 of the ICC Regulations of the Court does not obviate the need for cumulative charging as such a provision does not require trial chambers to re-characterise facts but only provides them with a possibility to do so.
} 
necessary to prove responsibility and subjective status, the document also highlights the policies it adopts to protect witnesses. The Document strengthens the commitment of the Prosecutor's Office to comply with its statutory obligations, in particular to take appropriate measures to protect the safety, physical and psychological well-being, dignity and privacy of victims and witnesses ${ }^{95}$. It states that it will "take into account the particular vulnerability of each of the witnesses and any additional care with regard to safety, personal, and/or family or social impact" ${ }^{\text {", }}$, and will "take all possible measures to prevent (...) harassment, intimidation and re-offense (...)"97.

The policy Document also reflects the intention to make changes in relation to its staff. During Moreno Ocampo's term of office, the Prosecutor's Office's investigation department was understaffed, with alternate teams of a "growing new staff" who conducted the investigations without a continuous presence on the field ${ }^{98}$. This fact, which has been compounded by persistent problems with culture management and the inadequacy of domestic staff, has led to the loss of a large number of experienced researchers and prosecutors.

Prosecutor Bensouda acknowledged abuse of the rotation practice of researchers. The Strategic Plan for the period 2012-2015 recognizes the need to increase the staff in the research department as well as greater researchers' experience, stating in particular: the new approach to investigations requires the Office to assess whether the existing mix of experience, specialization, language, gender and nationality is in line with the new conditions ${ }^{99}$.

The policy paper emphasizes the need for improved capabilities and operational expertise in sexual and gender violence as well as the value of continuing specialist training on issues such as the impact of trauma on vulnerable witnesses and methodologies for collecting and analyzing relevant information ${ }^{100}$. It should be noted, however, that tackling sexual and gender violence requires not only proper education and appropriate skills, but also the right "identities" ${ }^{101}$. The dynamics of gender in many cases are upgraded, for example when the two persons share the same gender identity ${ }^{102}$.

\section{VI.PROSPECTS AND SUGGESTIONS}

Surely, the publication of the drafting of policy document of Prosecutor's Office for sexual and gender crime is a remarkable progress. It represents a type of proclamation that there is a fundamental change in research and prosecution strategies, that were so

\footnotetext{
${ }^{95}$ Statute of Rome, art. 68, par. 1.

${ }^{96}$ OTP Policy Paper, para. 87.

${ }^{97}$ MCDERMOTT Y., SCHABAS W.A., Ashgate research companion to international criminal law. Critical perspectives, op. cit.

${ }^{98}$ DE VOS C.M., “Investigation from Afar: The ICC's evidence problem”, in Leiden Journal of International Law, 2013, pp. 1009ss

${ }^{99}$ ICC OTP, Strategic Plan 2012-2015, paras. 20-24. TRIFFTERER O., AMBOS K., The Rome statute of the International Criminal Court. A commentary, ed. C.H. Beck, Nomos, Oxford University Press, 2016.

${ }^{100}$ OTP Policy Paper, paras. 21, 28, 37, 57, 115, 117-119.

${ }^{101}$ Refugee Law Project, Comments on the ICC Draft Policy on Sexual and Gender Based Violence, Refugee Law Project, 23 February 2014, pag. 11,

${ }^{102}$ BIANCHI L., The prosecution of rape and sexual violence: Lessons from the prosecutions at the ICTR, op. cit., pp. 123-149.
} 
erroneous in the past and left huge gaps in international criminal justice ${ }^{103}$.

However, the significance of this document will only become meaningful if the policies described are properly and adequately implemented by increasing ICT cases concerning these crimes and the resulting improvement in domestic criminal case law. Some positive results from the strategic goals of the Office have already emerged since the newly elected Prosecutor Fatou Bensouda took office. Issuing an arrest warrant against Sylvestre Mudacumura ${ }^{104}$ and confirming the charges against Ntaganda are some of the most typical examples. However, it remains to be seen to what extent the Prosecutor will be able to overcome the practical difficulties so that the constitutional obligation of priority on sexual and gender-based crimes can now be implemented.

On the Prosecutor's side, the Policy Document is expected to help ensure effective investigation and prosecution of those specific crimes and maximize access to justice for victims through ICC. According to the Prosecutor, "it is expected that the Policy will also serve as a guide for national authorities in exercising their primary jurisdiction to make the perpetrators responsible for these crimes (...) the message to perpetrators and potential perpetrators must be clear: sexual and gender-based crimes in the conflict will neither be tolerated nor neglected by the Tribunal" 105 .

The question that arises is: Can human rights be the tool to overcome the challenges of international criminal justice?

Article 21(3) has been described as "one of the most important provisions of the Rome Statute” ${ }^{106}$. The obligation under Article 21(3) is widespread and requires all the institutions of the Tribunal to demonstrate the understanding of human rights violations constituting crimes contained in the Statute of ICC and how international human rights law can provide information and enlighten the applicable criminal law. The CEDAW Commission has already recognized since 1992 that "gendered violence is a form of discrimination that certainly affects the ability of women to enjoy rights and freedoms on the basis of equality with men" ${ }^{107}$. Regional human rights instruments have also pointed out that gender violence is "one of the most extreme and widespread forms of discrimination, greatly altering and abolishing the implementation of women's rights ${ }^{108}$.

This finding may indeed affect the way in which Courts analyze complaints of sexual and gender-based violence. Firstly, it requires Courts to recognize that sexual and gender violence occurring during periods of armed conflict are often part of a wider "image" of discrimination. It requires the Courts to recognize, for example, that rape, forced nakedness, sexual torture and other acts of a similar nature are often used to facilitate the

\footnotetext{
${ }^{103}$ MARINIELLO T., The International Criminal Court in search of its purpose and identity, ed. Routledge, 2014.

${ }^{104}$ Prosecutor v. Sylvestre Mudacumura, Case No. ICC-01/04-01/12, Prosecution application for a warrant of arrest, 13 June 2012 and Warrant of arrest issued by Pre-Trial Chamber II, 13 July 2012. (see in particular the paragraphs in relation on sexual crimes).

${ }^{105}$ Press Release, ICC, The Prosecutor of the International Criminal Court, Fatou Bensouda, Publishes Comprehensive Policy Paper on Sexual and Gender-Based Crimes, June 5, 2014,

${ }^{106}$ TRIFFTERER O., Commentary on the Rome Statute of the International Criminal Court, Observers' Notes. Article by article, Hart Publishing, 2008, pp. 712ss.

107 CEDAW Committee General Recommendation 19 on violence against women, UN Doc HRI/GEN/1/Rev7 (1992) para 1.

${ }^{108}$ Jessica Lenahan (Gonzales) v. United States, Inter-American Commission of Human Rights, Inter American Commission of Human Rights (21 July 2011), Case 12.626, Report 80/11, para 110.
} 
commission of other crimes because of the gender-related nature of many of them ${ }^{109}$.

The fact that international criminal justice has to deal with sexual and gender-based crimes as a form of discrimination as perceived by human rights law has already been codified in the Rome Statute, in particular Article $21(3)^{110}$. At the same time, it is duty of the Court to ensure that the interpretation and application of the Rome Statute is compatible with international human rights law and free of stereotypes of a distinct nature. As several commentators have noted, "while it is reasonable that human rights law can not be used to define international crimes such as persecution, this law can certainly be used to help interpret, where the absence of international criminal case law is evident" 111 . Persistent challenges can be addressed to a certain extent by the application of the fundamental principle of non-discrimination, encouraging international Courts to develop an improved understanding of when, why and how sexual violence takes place during armed conflicts, helping them better interpreted, what forms of criminal responsibility can and should be used to prosecute these crimes, what is the best way to deal with these crime systems, helping them reach equal justice.

\section{VII.CONCLUSIONS}

In practice, the two international criminal Tribunals have acknowledged that sexual violence can constitute a bunch of other additional crimes, including war crimes of torture $^{112}$ and attacks on personal dignity ${ }^{113}$, the crime against humanity not only of rape but also of sexual enslavement ${ }^{114}$, persecution, and the crime of genocide ${ }^{115}$. With regard to ICC, the statute of the latter includes specific gender-based crimes, such as rape, sexual slavery, forced prostitution, pregnancy and sterilization-on the basis of both war crime ${ }^{116}$ and crimes against humanity ${ }^{117}$. As regards the crimes of genocide, the elements of crimes state that although rape is not listed as a form of genocide, the latter caused by acts of "serious physical or mental harm"118, including "acts of torture, rape, sexual violence,

\footnotetext{
${ }^{109}$ SÁCOUTO S., Gaps in the gender-based violence jurisprudence of international and hybrid criminal Courts: Can human rights help?, in NGWENA C., DUROJAYE E. ( eds.), Strengthening the protection of sexual and reproductive health and rights in the African region through human rights, Pretoria University Law Press, 2014, pp. 319ss.

${ }^{110}$ VAGIAS M., The territorial jurisdiction of the International Criminal Court, Cambridge University Press, 2014, pp. 202ss.

${ }^{111}$ BROWN A., GRENFELL L., “The international crime of gender-based persecution and the Taliban”, in Melbourne Journal of International Law, 2003, pp. 360-361.

${ }^{112}$ See the case: Prosecutor v. Delalić, Mucuc, Delic and Lanzo, Case No.ICTY-IT-96-21-T, Trial Judgment, 16 November 1998, para. 475.

${ }^{113}$ Prosecutor v. Furundzija, Case No. ICTY-IT-95-17/1-T, Trial Judgment, 10 December 1998, para. 274.

${ }^{114}$ Prosecutor v. Kunarac Case No. ICTY-IT-96-23-T and IT-96-23/1-T, Trial Judgment, 22 February 2001, para. 436.

${ }^{115}$ Prosecutor v. Brdjanin, Case No ICTY-96-4-T, Trial Judgment, 1 September 2004, Trial Judgment, para. 15.

${ }^{116}$ DUBLER R., KALYK M., Crimes against humanity in the $21^{\text {st }}$ century. Law, practice and threats to international peace and security, ed. Brill, 2018.

${ }^{117}$ Prosecutor v. Akayesu, Case No. ICTR-96-4-T, Trial Judgment, 2 September 1998, para. 113 and Prosecutor v. Ndindilyimana et al, ICTR-00-56 of 30 June 2014.

${ }^{118}$ OOSTERVELD V., "Gender-sensitive justice and the International Criminal Tribunal for Rwanda”, in New England Journal of International and Comparative Law, 2005, pp. 119, 128ss. TROUILLE H., "How far has the international criminal Tribunal for Rwanda really core since Akayesu in the prosecution and investigation of sexual offenses committed against women? An analysis of Ndindilyimana et al.”, in
} 
inhuman or degrading treatment" ${ }^{\text {"119 }}$. However, the process of joining an act of sexual violence in the formal legal arena may be a painful process of many victims ${ }^{120}$. Not only can they experience a tremendous psychological strain because they have to go ahead and tell the violations against $i^{121}$, but they may be forced to confront it with the established gender bias and rape perceptions of the system itself responsible for providing justice.

Obstacles to the process are multiple: lack of effective cooperation between health care staff and legal system, structural and resource constraints on law enforcement, lack of forensic analysis and problems of the Courts themselves. Poor cooperation between investigators and prosecutors and the consequent inability to prove or attribute accusations and finally lack of sensitivity to judicial proceedings that "reconstitute" the victim's trauma ${ }^{122}$. But besides the victims, researchers and prosecutors may in turn encounter specific challenges, as they promote a case of sexual violence through the legal system. The often private character of rape ${ }^{123}$, for example, rarely offers the possibility of eyewitnesses, support that can be provided to other crimes. And whether the subject is the identity of the offender or the lack of consensus on sexual intercourse, prosecutors are often called upon to fight against gender bias or misconceptions about the nature of sexual violence.

\footnotetext{
International Criminal Law Review, 2013, pp. 750ss.

${ }^{119}$ International Criminal Court, Elements of Crimes, adopted on 9 September 2002, UN Doc. PCNICC/2000/1/Add.2, 2 November 2002.

${ }^{120}$ SCHÜNEMANN R., Strafverfahrensrecht, ed. C.H. Beck, 2012, pp. 439ss. SCHUON J., International criminal procedure: A clash of legal cultures, T.M.C. Asser press, 2010. SCHUETZE-REYMANN J., International criminal justice on trial. The ICTY and ICTR case referral practice to national Courts and its possible relevance for the ICC, ed. Duncker \& Humblot, 2016. SCHRAMM E., Internationales Strafrecht, C.H. Beck, 2011.

${ }^{121}$ Prosecutor v. Krstić, Judgement, IT-98-33-T, 2 August 2001, para. 616. In Prlić et al., Trial Chamber III found four out of six Accused guilty of some crimes, including rape, sexual violence, and looting on the grounds that the Accused could have reasonably foreseen that such crimes would be committed as a consequence of the implementation of the joint criminal enterprise, and that they nevertheless accepted and assumed that risk, including by taking no measure to prevent the commission of further crimes. Prosecutor v. Prlić et al., Judgement, IT-04-74-T, 29 May 2013, paras. 72, 284, 437, 834, and 1014. GUSTAFSON K., "The requirement of an "express agreement" for Joint Criminal Enterprise", in Journal of International Criminal Justice, 2007, pp. 138-158.

${ }^{122}$ European Center for Constitutional and Human Rights, Sisma Mujer and Collectivo de Abogados, ICC Communication on Sexual Violence in Colombia, pag. 11.

${ }^{123}$ See, Appeal Chamber, Prosecutor v. Ntaganda, Judgment on the appeal of Mr Ntaganda against the "Second decision on the Defence's challenge to the jurisdiction of the Court in respect of Counts 6 and 9", 15 June 2017, par. 16). For the first time, the ICC judges have enshrined that any question submitted to them, and therefore also those relating to the interpretation of war crimes, must be resolved only on the basis of the law of the founding charter. And secondly because in providing an interpretation of the aforementioned clause, the judges of the Chamber of Appeal seem to have given greater weight to the possibility of enhancing the object and purpose of the Statute rather than safeguarding the coherence and unity of the corpus of law and especially under international humanitarian. In this last perspective, it is important to underline the reference to the absolute prohibition of subjecting anyone to rape and sexual violence in the context of armed conflict, which appears without a shadow of doubt in line not only with the purpose of the ICC act, but above all with the evolution of international human rights law. Rigorous opinion that has found application of the nexus requirement to prevent an illegitimate expansion of the scope of war crimes rules in the Appeal Chamber, Prosecutor v. Ntaganda, Judgment on the appeal of $\mathrm{Mr}$ Ntaganda against the "Second decision on the Defence's challenge to the jurisdiction of the Court in respect of Counts 6 and 9”, 15 June 2017, par. 68.
} 
With regard to the proof of international sex crimes ${ }^{124}$, additional proofs arise: How can one collect consistent evidence of a crimes committed against countless people after many years? How can one assign responsibility to a military or political commander who may have never given a direct or immediate mandate to commit rape?

There are, however, many promising strategies for managing cases of sexual violence. These strategies have evolved, both in the domestic and international contexts. These may consist either of efforts to integrate awareness of sexual violence (as well as universal education across the range of research) or inter tactics aimed at developing expertise in the field of sexual violence crimes within the body of experts ${ }^{125}$. Innovations within an international body may have a significant impact on future developments within national or local criminal justice systems, including a context of more extensive use of gender experts, increased coordination between prosecutors and investigations and the increased protection measures of witnesses ${ }^{126}$.

Indeed, the new Prosecutor's Office Paper on Gender and Sexual Crimes provides a set of coherent and integrated goals towards more effective justice and recognition of the harm suffered by victims of sexual and gender-based violence, in the context of permanent international jurisdiction instrument. Whether the ICC will eventually become the catalyst for the eradication of sexual violence, mainly as a weapon ${ }^{127}$ or war strategy ${ }^{128}$, and how soon it will be demonstrated by the progress it will make in the next period.

Already documented cases of sexual violence in Colombia ${ }^{129}$ offer an excellent opportunity to the Prosecutor's Office to apply this new approach that has been adopted in the Policy Document. Besides, the ICC already has reason to believe that the Revolutionary Armed Forces of Colombia (FARC) committed crimes against the civilian population in Colombia ${ }^{130}$, which are violations of the Rome Statute ${ }^{131}$, and has already stated that it will proceed to prosecution of the international crimes committed in Colombia if the Colombian Government does not manage to do so effectively. While international law provides the platform for the recognition of a set of universal rights, it is only the starting point from which the appropriate approach to justice will be diversified. Although the ICC is currently focusing on the investigation of situations in African countries and not only ${ }^{132}$, it is crucial to distinguish the details of sexual violence in different contexts in order to formulate responses that respond to the particular need of

\footnotetext{
${ }^{124}$ BERGSMO M., Thematic prosecution of international sex crimes some critical comments from a theoretical and comparative perspectives, ed. Torkel Opshahl Academic Epublisher, Beijing , Beijing, 2012, pp. 294ss.

${ }^{125}$ AHLBRECHT H., BÖHMEER K., Internationales Strafrecht, C.F. Müller, 2018.

${ }^{126}$ SQUATRITO T., YOUNG O., FOLLESDAL A., ULSTEIN G., The performance of international Courts and Tribunals, Cambridge University Press, 2018.

${ }^{127}$ KIRBY P., "How is rape a weapon of war? Feminist International Relations, modes of critical explanation and the study of wartime sexual violence”, in European Journal of International Relations, 2012, pp. 802ss. ${ }^{128}$ BUSS D., "Rethinking "rape as a weapon of war", in Feminist Legal Studies, 2009, pp. 152ss.

${ }^{129}$ COLE A., International criminal law and sexual violence, in MCGYNN, MUNRO (eds.), Rethinking rape law. International and comparative perspectives, ed. Routledge, 2010, pp. 49ss.

${ }^{130}$ BOESTEN J., "Analyzing rape regimes at the interface of war and peace in Peru", in The International Journal of Transitional Justice, 2010, pp. 112ss. BOESTEN J., WILDING P., "Transformative gender justice: Setting an agenda", in Women's Studies International Forum, 2015, pp. 77ss.

${ }^{131}$ Office of the Prosecutor, Situation in Colombia: Interim Report, November 2012, pag. 8.

${ }^{132}$ VILJOEN F., International human rights law in Africa, Oxford University Press, 2012.
} 
survivors and communities, and this can achieved only if survivors are incorporated into the process of redefining how they see justice themselves, especially in ways that fit their country's political history and culture. If the ICC wants to play the role of deterring the most serious human tights violations and make progress to that end, it must integrate gender equality more prominently across the range of proceedings before the Court ${ }^{133}$.

\section{BIBLIOGRAPHY}

ABTAHI H., KOH S.A., "The emerging enforcement practice of the International Criminal Court” in Cornell International Law Journal, 2012, pp. 1ss.

ACEVEDO P.L., “The legitimacy of international criminal Tribunals”, in Nordic Journal of Human Rights, 2017, pp. 164ss.

ACQUAVIVA G., War crimes at the ICTY: Jurisdictional and substantive issues, in BELLELLI R. (a cura di), International criminal justice. Law and practice from the Rome Statute to its review, Ashgate publishing, 2010, pp. 299ss.

AGNEW A., "Acquittals in Mugenzi \& Mugiraneza v. Prosecutor contribute to the weak legacy of the International Criminal Tribunal for Rwanda", in Boston College International \& Comparative Law Review, 2015, pp. 8ss.

AHLBRECHT H., BÖHMEER K., Internationales Strafrecht, C.F. Müller, 2018.

AHMAD H., "Context at the International Criminal Court", in Pace International Law Review, 2017, pp. 132ss.

ALEXANDER JF., "The International Criminal Court and the prevention of atrocities: Predicting the Court's impact”, in Villanova Law Review, 2009, pp. 27ss.

AMBOS K, ACKERMAN B., Liber amicorum Mirjam Damaška. Beiträge zum Internationalen und Europäischen Strafrecht, Duncker \& Humblot, 2016.

AMBOS K., "Critical Issues in the Bemba decision”, in Leiden Journal of International Law, 2009, pp. 715-26.

AMBOS K., "The crime of aggression after Kampala", in German Yearbook of International Law, 2010, 478, 501-504.

AMBOS K., Individual criminal responsibility, in TRIFFTERER (ed.), Commentary on the Rome Statute of the International Criminal Court: Observers'Notes, Article by Article, $2^{\text {nd }}$ ed., C.H. Beck/Hart/Nomos, 2008, pp. 795-843.

AMBOS K., Internationales Strafrecht, C.H. Beck, 2018.

AMBOS K., Sexual offences in international criminal law, with a special focus on the Rome Statute of the International Criminal Court (July 3, 2012), in BERGSMO M., BUTENSCHØN A., SKRE WOOD E.J. (eds.), Understanding and proving international sex crimes, Torkel Opsahl Academic Epublisher, Beijing, 2012, pp. 144ss.

AMBOS K., STEGMILLER I., "Prosecuting international crimes at the International Criminal Court: Is there a coherent and comprehensive prosecution strategy?", in Crime, Law and Social Change, 2013.

AMBOS K., Treatise on unternational criminal law: vol. 2: The crimes and sentencing, Oxford University Press, 2014.

ARCHIBUGI D., PEASE A., Crime and global justice: The dynamics of international punishment, ed. Polity, 2018.

\footnotetext{
${ }^{133}$ DAVIDSON G., "How to read international criminal law: Strict construction and the Rome Statute of the International Criminal Court", in Saint John's Law Review, 2017, pag. 4.
} 
BABINGTON-ASHAYE A., COMRIE A., ADENIRAN A., International criminal investigations: Law and practice, Eleven International Publishing, 2018.

BACHAROVA T., The standing of victims in the procedural design of the ICC, ed. Brill, 2017.

BADAR M., HIGGINS N., General principles of law in the early jurisprudence of the ICC, in MARINIELLO T. (ed.), The International Criminal Court in search of its purpose and identity, ed. Routledge, 2014.

BADAR M., PORRO S., Rethinking the mental elements in the jurisprudence of the ICC, in STAHN C. (ed.), The law and practice of the International Criminal Court, Oxford University Press, 2015.

BADAR M., The concept of mens rea in international criminal law. The Case for a unified approach, Hart Publishing, 2013.

BADAR M.E., "Dolus eventualis and the Rome Statute without it?", in New Criminal Law Review, 2009, pp. 436ss.

BARRIGA S., GROVER L., “A historic breakthrough on the crime of aggression”, in American Journal of International Law, 2011, pp. 518ss.

BENSOUDA F., "Reflections from the International Criminal Court Prosecutor", in Case Western Journal of International Law, 2012, pp. 506ss.

BERGSMO M., Thematic prosecution of international sex crimes some critical comments from a theoretical and comparative perspectives, ed. Torkel Opshahl Academic Epublisher, Beijing, Beijing, 2012, pp. 294ss.

BIANCHI L., The prosecution of rape and sexual violence: Lessons from prosecution at the ICTR, in DE BROUWER AM. Et al. (eds.), Sexual violence as an international crime: Interdisciplinary approaches, ed. Intersentia, 2013, pp. 125ss.

BOESTEN J., "Analyzing rape regimes at the interface of war and peace in Peru”, in The International Journal of Transitional Justice, 2010, pp. 112ss.

BOESTEN J., WILDING P., “Transformative gender justice: Setting an agenda”, in Women's Studies International Forum, 2015, pp. 77ss.

BOSLY H., VANDERMEERSCH D., Gènocide, crimes contre l'humanitè et crimes de guerre face à la justice, ed. Bruylant, 2012.

BRADY H., "The power of precedents: using the case law of the ad hoc international criminal Tribunals and hybrid Courts in adjudicating sexual violence and gender-based crimes at the ICC”, in Australian Journal of Human Rights, 2012.

BROWN A., GRENFELL L., "The international crime of gender-based persecution and the Taliban”, in Melbourne Journal of International Law, 2003, pp. 360-361.

BROWN B.S., Research handbook on international criminal law, Edward Elgar Publishing, 2011, pp. 86ss.

BUSS D., "Rethinking “rape as a weapon of war”, in Feminist Legal Studies, 2009, pp. 152ss.

CARPENTER R.C., "Recognizing gender-based violence against civilian men and boys in conflict situations”, in Security Dialogue, 2006, pp. 98-99.

CASSESE A., (ed.), International criminal law, Oxford University Press, 2013.

CHAPPELL L., The politics of gender justice at the International Criminal Court, Oxford University Press, 2016, pp. 266ss.

CHIEDU MOGHALU K.C., "International humanitarian law from Nuremberg to Rome: The weighty precedents of the international criminal Tribunal for Rwanda", in Pace 
International Law Review, 2002, pp. 285ss.

CLARK R.S., "Amendments to the Rome Statute of the International Criminal Court considered at the first review Conference on the Court, Kampala, 31 May-11 June 2010”, in Goettingen Journal of International Law, 2010, pp. 690ss.

COHEN D.C. Et al, Wartime sexual violence: Misconceptions, implications, and ways forward, Washington DC, United States Institute of Peace, February 2013, pp. 7.

COLE A., International criminal law and sexual violence, in MCGLYNN C., MUNRO V.E., Rethinking rape law. International and comparative perspectives, ed. Routledge, 2010, pp. 49ss.

DANNENBAUM T., The crime of aggression, humanity and the soldier, Cambridge University Press, 2018.

DAVID R., "International criminal Tribunals and the perception of justice: The effect of the ICTY in Croatia”, in International Journal of Transitional Justice, 2014, pp. 478ss.

DAVIDSON C., "How to read international criminal law: Strict construction and the Rome Statute of the International Criminal Court”, in Saint John's Law Review, 2017, pag. 4.

DE GUZMAN M.M., "How serious are international crimes? The gravity problem in international criminal law”, in Columbia Journal of Transnational law, 2012, pp. 20ss.

DE RUITER D., VAN DER WOLF D., Aggression and international criminal law, Wolf Legal Publishers, 2011.

DE VOS C.M., “Investigation from Afar: The ICC's evidence problem”, in Leiden Journal of International Law, 2013, pp. 1009ss.

DEFALCO R.C., "Accounting for famine at the Extraordinary Chambers in the Courts of Cambodia. The crimes against humanity of extermination, inhumane acts and persecution”, in The International Journal of Transitional Justice, 2011.

DINSTEIN Y., War, aggression and self-defence, Cambridge University Press, 2011.

DONDÉ MATUTE J., "Responsabilidad penal internacional: Los nuevos escenarios dogmàticos”, in Anuario Mexicano de Derecho Internacional, 2018.

DUBLER R., KALYK M., Crimes against humanity in the $21^{\text {st }}$ century. Law, practice and threats to international peace and security, ed. Brill, 2018.

EBOE-OSUJI C., International law and sexual violence in armed conflicts, ed. Brill, 2012, pp. 146ss.

EBOE-OSUJI C., "The ICC and the African Court and the estended notion of complementarity of international criminal jurisdictions", in Nigeria Yearbook of International Law, 2018.

ERIKSSON BAAZ M., STERN M., The complexity of violence: A critical analysis of sexual violence in the Democratic Republic of Congo, Nordiska Afrikaininstitutet and Sida, 2010, pp. 7-14, 41-50.

FAIRLIE M.A., "The United States and the International Criminal Court post-Bush: A beautiful courtship but an unlikely marriage", in Berkeley Journal of International Law, 2011, pp. 530ss.

FENRICK W., Article 28, in TRIFFTERER O. (ed.), Commentary on the Rome Statute of the International Criminal Court, Nomos Verlagsgesellschaft, Baden-Baden, 1999, pp. 518-520.

FINNIN S., "Mental elements under article 30 of the Rome statute of the International Criminal Court. A comparative analysis”, in International \& Comparative Law Quarterly, 
2012, pp. 328ss.

GALÁN A., STONE J., “Aggression and the future of the International Criminal Court”, in International Law Review, 2018.

GALÁN J.S., J"ulius Strong, aggression and the future of the International Criminal Court”, in International Criminal Law Review, 2018, pp. 306ss.

GIL GIL A., "Mens rea in co-perpetration and indirect perpetration according to article 30 of the Rome Statute. Arguments against punishment for excesses committed by the agent or the co-perpetrator”, in International Criminal Law Review, 2014, pp. 85ss.

GILLETT M., "The anatomy of an international crime aggression at the International Criminal Court”, in International Criminal Law Review, 2013, pp. 832ss.

GLENNON M., “The blank-prose crime of aggression”, in Yale Journal of International Law, 2010, pp. 71-102.

GUSTAFSON K., “The requirement of an "express agreement” for Joint Criminal Enterprise”, in Journal of International Criminal Justice, 2007, pp. 138-158.

HAGAY-FREY A., Sex and gender crimes in the new international law: Past, present, future, Martinus Nijhoff Publishers, 2011, pp. 80ss.

HAJDIN N., "The nature of leadership in the crime of aggression The ICC's new concern?”, in International Criminal Law Review, 2017, pp. 545ss.

HALLEY J., "Rape in Berlin: Reconsidering the criminalisation of rape in the international law of armed conflict”, in Melbourne Journal of International Law, 2008, pp. 80ss.

HEINSCH R., "The crime of aggression after Kampala: Success or burden for the future?”, in Goettingen Journal of International Law, 2010, 715-740.

HELLER K.J., "What is an international crime?”, in Harvard International Law Journal, 2018.

HELLER K.J., The Rome Statute of the International Criminal Court, in HELLER J., DUBER M.D. (eds.), The Handbook of comparative criminal law, Stanford Law Books, Stanford, 2011, pp. 594ss.

HELLER K.J., SIMPSO G. (eds), The hidden histories of war crimes trials, Oxford University Press, 2013.

HELLWIG-BÖTE M., "Political bickering over the International Criminal Court: The Case of Kenya, January 2014”, Stiftung Wissenschaft Politik, 2015.

HOYLE L., "Command responsibility-A legal obligation to deter sexual violence in the military", in Boston College International \& Comparative Law Review, 2014, pp. 354ss. JAIN N., Going beyond prosecutorial discretion: Institutional factors influencing thematic prosecution, in BERGSMO M., Thematic prosecution of international sex crimes, Beijing, 2012, pp. 208ss.

JANJAC K., The mental element in the Rome statute of the International Criminal Court, Wolf Legal Publishers, 2013.

KEMP G., Individual criminal liability for the international crime of aggression, Cambridge University Press, 2017.

KIRBY P., "How is rape a weapon of war? Feminist International Relations, modes of critical explanation and the study of wartime sexual violence”, in European Journal of International Relations, 2012, pp. 802ss.

KRESS C, BARRIGA S., The crime of aggression, Cambridge University Press, 2017. KRESS C., "On the activation of ICC jurisdiction over the crime of aggression", in 
Journal of International Criminal Justice, 2018.

KRESS C., VON HOLTZENDORFF L., "The Kampala compromise on the crime of aggression”, in Journal of International Criminal Justice, 2010, pp. 1195-1206.

LANGSTON L., "No penetration-and it's still rape”, in Pepperdine Law Review, 1999, pp. 6ss.

LEWIS D.A., "Unrecognized victims: Sexual violence against men in conflict settings under international law", in Wisconsin Journal of International Law, 2009, pp. 24ss.

LIAKOPOULOS D., Parità di armi nella giustizia penale internazionale, vol. 1, ed. Libellula University Press, 2018.

MANIVANNAN A., "Seeking justice for male victims of sexual violence in armed conflicts”, in International Law and Politics, 2014, pp. 654ss.

MANIVANNAN A., "Seeking justice for male victims of sexual violence in armed conflicts”, in New York University of Journal of International Law and Politics, 2014, pp. 638ss.

MANSON R.L., "Identifying the rough edges of the Kampala compromise", in Criminal Law Forum, 2010, pp. 418ss.

MARCZAK N., SHIELDS K., Genocide perspective V: A global crime, UTS ePress, 2017. MARINIELLO T., The International Criminal Court in search of its purpose and identity, ed. Routledge, 2014.

MCDERMOTT Y, SCHABAS W.A., Ashgate research companion to international criminal law. Critical perspectives, ed. Routledge, 2016.

MCDOUGALL C., The crime of aggression under the Rome statute of the International Criminal Court, Cambridge University Press, 2013.

MEISENBERG S., The extraordinary Chambers in the Courts in Cambodia. Assessing their contribution to international criminal law, ed. Springer, 2016.

MELLOH F., Einheitliche Strafzumessung in den Rechtsquellen des ICC-Statuts, Dunker\&Humblot, 2010.

MELONI C., Fragmentation of the notion of co-perpetration in international criminal law, in VAN DEN HERIK L., STAHN C. (eds.), The diversification and fragmentation of international criminal law, ed. Brill, 2012, pp. 501-502. YANEN, Theories of coperpetration in international criminal law, ed. Brill, 2018.

MIBENGE C.S., Sex and international Tribunals: The erasure of gender from the war narrative, University of Pennsylvania Press, 2013.

MOUTHAAN S., "Sexual violence against men and international law criminalising the unmentionable", in International Criminal Law Review, 2013, pp. 667ss.

MOUTHAAN S., "The prosecution of gender-based crimes at the ICC: Challenges and opportunities”, in International Criminal Law Review, 2011, pp. 776ss.

MOUTHAAN S., "Victim participation at the ICC for victims of gender-based crimes: A conflict of interest?”, in Cardozo Journal of International and Comparative Law, 2013, pp. 619ss.

MUDGWAY C., "Sexual exploitation by UN peacekeepers: the "survival sex" gap in international human rights law", in The International Journal of Human Rights, 2017.

MUELLER S.D., "Kenya and the International Criminal Court (ICC): Politics, the election and the law", in Journal of Eastern African Studies, 2014, pp. 5ss.

MUKUM MBAKU J., "International justice: The International Criminal Court and Africa, January 2014, Foresight Africa: Top Priorities for the Continent in 2014 “, The Brookings 
Africa Growth Initiative, 2015.

NÍ AOLÀIN F. et al., On the frontlines: Gender, war, and the post-conflict process, Oxford University Press, 2011, pp. 49-55.

NIAHM H., La lutte continue: Investigating and prosecuting sexual violence at the ICC, in STAHN C., The law and practice of the International Criminal Court, Oxford University Press, 2015, pp. 831ss.

NIGGLI M.A., HEIMGARTNER ST., Internationales Strafrecht, Helbing Lichtenhahn, 2015.

NOVAK A., The International Criminal Court: An Introduction, ed. Springer, 2015.

NYBONDAS M.L., Command responsibility and its applicability to civilian leaders, ed. TMC Asser Press, 2010.

O'CONNELL J., "Gambling with the psyche: Does prosecuting human rights violators console their victims?”, in Harvard International Law Journal, 2005, pp. 312ss.

OOSTERHOFF O., "Sexual torture of men in Croatia and other conflict situations: an open secret”, in Reproductive Health Matters, 2004, pp. 68ss.

OOSTERHOFF P., ZWANIKKEN P., KETTING E., "Sexual torture of men in Croatia and other conflict situations: An open secret”, in Reproductive Health Matters, 2014, pp. 70-71.

OOSTERVELD V., "Gender-sensitive justice and the International Criminal Tribunal for Rwanda”, in New England Journal of International and Comparative Law, 2005, pp. 119, 128ss.

OOSTERVELD V., "Sexual violence against men and boys in armed conflict or mass atrocity: Addressing a gendered harm in international criminal Tribunals", in Journal of International Law and International Relations, 2014, pp. 118ss.

O’REGAN F., "Prosecutor vs. Jean-Pierre Bemba Gombo: The cumulative charging principle, Gender-based violence, and expressivism", in Georgetown Journal of International Law, 2012, pp. 1344ss.

PALMER E., WILLIAMS S., “A "shift in attitude”? Institutional change and sexual and gender-based crimes at the Extraordinary Chambers in the Courts of Cambodia”, in International Feminist Journal of Politics, 2017.

PARASHAR S., "What wars and "war bodies" know about international relations", in Cambridge Review of International Affairs, 2013, pp. 621ss.

PÈREZ-LEÓN-ACEVEDO J.P., "The Katanga reparation order at the International Criminal Court developing the emerging reparation, practice of the Court”, in Nordic Journal of Human Rights, 2018.

PILLAY N., “Sexual violence: Standing by the victim”, in Case Western Reserve Journal of International Law, 2009, pp. 462ss.

PIRAGOFF D., Mental element, in AMBOS K., TRIFFTERER O., The Rome statute of the International Criminal Court, ed. Nomos, Hart Publishing, C.H. Beck, 2016, pp. 114 ss.

POLITI M., "The ICC and the crime of aggression. A dream that came through and the reality ahead”, in Journal of International Criminal Justice, 2012, pp. 268ss.

PORRO S., Risk and mental element: An analysis of national and international law on core crimes, ed. Nomos, 2014.

RAMJI-NOGALES J., "Questioning hierarchies of harm: Women, forced migration and international criminal law”, in International Criminal Law Review, 2011. 
REISINGER CORACINI A., "The International Criminal Court's exercise of jurisdiction over the crime of aggression-at Least...in reach...over some”, in Goettingen Journal of International Law, 2010, pp. 748-788.

RUSSELL W., "Sexual violence against men and boys”, in Forced Migration Review, 2007, pp. 22, 23.

SÁCOUTO S., "Victim participation at the International Criminal Court and the Extraordinary Chambers in the Courts of Cambodia: A feminist project”, in Michigan Journal of Gender \& Law, 2012, pp. 298ss.

SÁCOUTO S., Gaps in the gender-based violence jurisprudence of international and hybrid criminal Courts: Can human rights help?, in NGWENAC., DUROJAYE E. ( eds.), Strengthening the protection of sexual and reproductive health and rights in the African region through human rights, Pretoria University Law Press, 2014, pp. 319ss.

SÁNCHEZ REVERTE A., "Referencia al crimen de genocidio aproximation genocide crime”, in Revista de Estudios Juridicos (segunda època), 2016.

SATZGER H., SCHLUCKEBIER W., WIDMAIER G., Strafprozessordung (StPO), Carl Heymanns Verlag, 2017.

SAYAPIN S., The crime of aggression in international criminal law. Historical development, comparative analysis and present State, ed. Springer, 2014.

SCHABAS W.A., The International Criminal Court, A commentary to the Rome Statute, Oxford University Press, 2008, pp. 424ss.

SCHEFFER D., “The complex crime of aggression under the Rome Statute”, in Leiden Journal of International Law, 2010, pp. 898ss.

SCHEFFER D., The Extraordinary Chambers in the Courts of Cambodia, in BASSIOUNI M.C., International Criminal Law, ed. Brill, 2008, pag. 253.

SCHRAMM E., Internationales Strafrecht, C.H. Beck, 2011.

SCHUETZE-REYMANN J., International criminal justice on trial. The ICTY and ICTR case referral practice to national Courts and its possible relevance for the ICC, ed. Duncker \& Humblot, 2016.

SCHÜNEMANN R., Strafverfahrensrecht, ed. C.H. Beck, 2012, pp. 439ss.

SCHUON C., International criminal procedure: A clash of legal cultures, T.M.C. Asser press, 2010.

SIVAKUMARAN S., "Lost in translation: UN responses to sexual violence against men and boys in situations of armed conflict", in International Review of the Red Cross, 2010, pp. 259, 264ss.

SIVAKUMARAN S., "Male/Male rape and the "taint" of homosexuality", in Human Rights Quarterly, 2005, pp. 1288ss.

SIVAKUMARAN S., "Sexual violence against men in armed conflict", in European Journal of International Law, 2007, pp. 254.

SIVAKUMARAN S., Prosecuting sexual violence against men and boys, in DE BROUWER A.M. Et al. (eds.), Sexual violence as an international crime: Interdisciplinary approaches, ed. Intersentia, 2013, pag. 82.

SMALENBACH K., "Das Verbrechen der Aggression vor dem Internationalen Strafgerichtshof: Ein politischer Erfolg mit rechtlichen Untiefen”, in Jurist Zeitung, 2010, 745-748.

SQUATRITO T., YOUNG O., FOLLESDAL A., ULSTEIN G., The performance of international Courts and Tribunals, Cambridge University Press, 2018. 
STEMPLE L., “Male rape and human rights”, in Hasting Law Journal, 2009, pp. 619ss. SVÁČEK O., "Brothers and sisters in arms as victims of war crimes. Ntagada case before the ICC”, in Czech Yearbook of Public \& Private International Law, 2018.

TRAHAN J, “The Rome Statute's amendment on the crime of aggression: Negotiations at the Kampala Review Conference”, in International Criminal Law Review, 2011, pp. 49ss.

TRAHAN J., "From Kampala to New York. The final engotiations to activate the jurisdiction of the International Criminal Court over the crime of aggression", in International Criminal Law Review, 2018, pp. 198ss.

TRAHAN J., "From Kampala to New York. The final negotiations to activate the jurisdiction of the International Criminal Court over the crime of aggression", in International Law Review, 2018.

TRIFFTERER O., Commentary on the Rome Statute of the International Criminal Court, Observers' Notes. Article by article, Hart Publishing, 2008, pp. 712ss.

TRIFFTERER O., AMBOS K., The Rome statute of the International Criminal Court. A commentary, ed. C.H. Beck, Nomos, Oxford University Press, 2016.

TROUILLE H., "How far has the international criminal Tribunal for Rwanda really core since Akayesu in the prosecution and investigation of sexual offenses committed against women? An analysis of Ndindilyimana et al.”, in International Criminal Law Review, 2013, pp. 750ss.

VAGIAS M., The territorial jurisdiction of the International Criminal Court, Cambridge University Press, 2014, pp. 202ss.

VAN DEN HERIK L., STAHN C. (eds.), The diversification and fragmentation of international criminal law, ed. Brill, 2012, pp. 501-502.

VAN SCHAAK B., "Negotiating at the interface of power and law: The crime of aggression”, in Columbia Journal of Transnational Law, 2011, pp. 506ss.

VEST H., Völkerrechtsverbrechen verfolgen. Ein abgestuftes Mehrebenenmodell systemischer Tatherrschaft, C.H. Beck, 2011.

VILJOEN F., International human rights law in Africa, Oxford University Press, 2012. VISEUR-SELLERS P.V., "Gender strategy is not a luxury for international Courts", in American University Gender, Society Policy \& Law, 2009, pp. 302ss.

VON BRAUN L., MICUS A., "Judicial independence at risk: Critical issues regarding the crime of aggression raised by selected human rights organizations", in Journal of International Criminal Justice, 2012, pp. 112ss.

WACHALA K., “The tools to combat the war on women's bodies: Rape and sexual violence against women in armed conflict”, in The International Journal of Human Rights, 2012.

WATERLOW J., SCHUHMACHER J., War crimes trials and investigations. A multidisciplinary introdcution, Oxford University Press, 2018.

WEIGEND T., "Intent, mistake of law, and co-perpetration in the Lubanga Decision on confirmation of charges“, in Journal of International Criminal Justice, 2008, pp. 474ss.

WEISBORD N., “Conceptualizing aggression”, in Duke Journal of Comparative International Law, 2009.

WERLE J, JESSBERGER F., Principles of international criminal law, $3^{\text {rd }}$ ed., Oxford University Press, 2014, pp. 795ss.

WERLE J., "Individual criminal responsibility in Article 25 ICC Statute“, in Journal of 
International Criminal Justice, 2007, pp. 954ss.

WERLE J., Völkerstrafrecht, ed. M. Siebeck, 2012, pp. 610ss.

WILLIAMS S., OPDAM J., "The unrealised potential for transformative reparations for sexual and gender-based violence in Sierra Leone," in The International Journal of Human Rights, 2017, pp. 1284ss.

WOLFE L., "Blind spot: Why do convictions for the world's worst crimes neglect survivors of rape?”, in Foreign Policy, 12 March 2014.

YANEV N., Theories of co-perpetration in international criminal law, ed. Brill, 2018. YANG G., International Criminal Court: A judicial guarantee for international peace and security, in BERGSMO M., LING Y., State sovereignty and international criminal law, Torkel Opshal Academic Epublisher, 2012, pp. 98ss.

YASUAKI O., International law in a transcivilizational world, Cambridge University Press, 2017.

ZAWATI H.M., "Impunity or immunity: Wartime male rape wants sexual torture as a crime against humanity”, in Torture, 2007, pp. 34ss.

ZIMMERMANN A., "Amending the amendment provisions of the Rome Statute”, in Journal of International Criminal Justice, 2012, pp. 210ss. 